\title{
O Estado Esquadrão da Moda: um ensaio sobre indumentária, religião e autoritarismo em três estados democráticos de direito ${ }^{1}$
}

\author{
Cláudia Türner Pereira Duarte \\ Mestre em Direito Público pela Universidade do Estado do Rio de Janeiro (UERJ). Bacharel \\ em Direito pela UERJ. Promotora de Justiça (MPRJ). E-mail: clauturner@yahoo.com.br
}

\section{Resumo}

$O$ presente artigo tem por objetivo aprofundar os estudos sobre $o$ ato de vestir-se como uma projeção da liberdade individual e religiosa, por meio da análise histórica, social, política e jurídica de três Estados Democráticos de Direito, quem, nos últimos anos, estiveram no centro desse debate: a Turquia, a França e a Alemanha. Trata-se de estudo inspirado nas reflexões sobre o pós-secularismo (Habermas), o multiculturalismo (Will Kymlicka) e a ideia de justiça como reconhecimento (Nancy Fraser). O processo de pesquisa que fundamentou este trabalho, por sua vez, foi construído a partir das linhas metodológicas propostas pelos consagrados autores de Direito Constitucional Comparado, Ran Hirschl e Vicki C. Jackson, a saber, a necessidade de conjugar a análise do arcabouço jurídico estrangeiro ao contexto histórico e social que Ihe é subjacente. Com efeito, buscou-se ampliar as fontes de pesquisa para além daquelas tradicionalmente utilizadas

\footnotetext{
${ }^{1}$ A primeira versão deste artigo foi elaborada no ano de 2014, antes do golpe e do contragolpe de Estado, na Turquia. Com efeito, o reconhecimento da Turquia como um Estado democrático de Direito tornou-se de repente um ponto sensível. Como sustentar que um regime que abruptamente aniquila garantias fundamentais de juristas, jornalistas, professores, acadêmicos, opositores políticos e Ministros da Corte Constitucional, abrindo mão da sua adesão às normas protetivas de direitos fundamentais elaboradas pelas instituições europeias pode ser classificado como tal? A Turquia está, pois, neste instante, nessa zona fronteiriça, uma estrutura democrática organizada que avançou a galope rumo ao pântano do autoritarismo. Manteremos, contudo, a análise nestes termos, levando-se em consideração o histórico recente da Turquia como um sistema de governo organizado em torno de um Estado democrático de Direito. No geral, porém, os eventos recentes da Turquia evidenciam um dos principais pontos desse trabalho: o reconhecimento de que nenhum desses Estados está imune ou livre de matizes autoritários, que transitam no sistema, ora arrefecendo o significado real da proteção aos direitos fundamentais, ora em busca de uma reorganização capaz de catapultar a si próprio para a o patamar de força hegemônica estatal.
}

Revista Publicum

Rio de Janeiro, v.2, n. 2, 2016, p. 254-323

http://www.e-publicacoes.uerj.br/index.php/publicum

DOI: $10.12957 /$ publicum.2016.26368 
na área do Direito - leis, jurisprudência e doutrina - para abarcar livros e artigos das áreas de moda, sociologia, antropologia e história. Além disso, considerando um dos principais e reconhecidos desafios do estudo do direito constitucional comparado - o idioma estrangeiro - a pesquisa buscou fontes de notícias internacionais, capazes de relatar eventos recentes na história desses países. Nessa esteira, a utilização de notícias de jornais e periódicos online serviu muito bem para o propósito deste estudo: identificar os principais eventos históricos, sobretudo recentes, dos países estudados. Pretendeu-se com isso, como objetivo geral, demonstrar como a análise dos arranjos jurídicos deve ser realizada em conjunto com o complexo histórico e social no qual se insere. De mais a mais, a pesquisa não pretendeu buscar períodos históricos específicos, mas sim utilizar como ponto de partida os momentos de gênese dos países estudados responsáveis por moldar o seu perfil na atualidade: (i) o surgimento da Turquia como Estado-Nação; (ii) a Revolução Francesa; e (iii) a consagração da Alemanha como uma democracia constitucional soerguida sob a égide da Lei Fundamental de Bonn, após a Segunda Guerra Mundial. Concluímos, pois, que existe uma tendência histórica, que se perpetua até mesmo nos ditos Estados democráticos de Direito, de cercear o ser humano nas suas escolhas individuais e pessoais diferentes daquelas usualmente reconhecidas pelo status quo. O uso da vestimenta, sobretudo a religiosa, é um exercício de resistência e resiliência de defesa da manutenção de um espaço de liberdade pessoal, que se pretende inacessível aos Estados - um dos últimos bastiões de liberdade do ser humano. Este trabalho inserese na temática ampla de pesquisa da autora, voltada ao reconhecimento do Direito como parte integrante e indissociável da história, das relações entre crianças, famílias, sociedade, escola, religião e Estado, e, sobretudo, da consagração da liberdade humana como elemento essencial de Estados que se estruturam sob a égide de uma democracia constitucional.

Palavras-chave

Autoritarismo; Alemanha; Estado Democrático de Direito; França; Indumentária; Liberdades individual e religiosa; Turquia; Véu Islâmico.

\title{
State Fashion Police: an essay about dressing, religion and authoritarianism in three democratic rule of law states
}

\begin{abstract}
This article aims at deepening the studies on the act of dressing as a projection of individual and religious freedom through the historical, social, political and judicial analysis of three democratic rule-of-law states, which in recent years have been at the center of this debate, namely Turkey, France and Germany. It is a study inspired by the reflections on post-secularism (Habermas), multiculturalism (Will Kymlicka) and the idea of justice as recognition (Nancy Fraser). The research process that grounded this work, in turn, was built on the methodological lines proposed by the established authors of Comparative Constitutional Law, Ran Hirschl and Vicki C. Jackson, that is to say, the need to combine the analysis of the foreign legal framework with the historical and social context that underlies it. In fact, we sought to expand the sources of research beyond those traditionally used in the area of Law - laws, jurisprudence and doctrine - including books and articles in the fields of fashion, sociology, anthropology and history. Furthermore, in the light of one of the major and recognized challenges of comparative constitutional law - foreign languages -, the research sought international news sources capable of reporting recent events in the history of those countries. In this sense, the use of online news posted by newspapers and periodicals served very well for the purpose of this study by identifying the main historical events of the countries we studied, especially
\end{abstract}


recent ones. As a general objective, we intended to demonstrate how the analysis of legal framework should be carried out in conjunction with the historical and social complex in which it is inserted. Moreover, the research did not intend to seek specific historical periods, but rather use as a starting point the moments of genesis of the countries we studied responsible for shaping their profile of these days: (i) the emergence of Turkey as a Nation State; (ii) the French Revolution; and (iii) the legitimation of Germany as a constitutional democracy back on its feet under the aegis of the Fundamental Law of Bonn after World War II. As a conclusion, it can be said that there is a historical tendency, which is perpetuated even among such so-called democratic rule-of-law states, to restrain human beings from individual and personal choices which are different from those usually accepted by the status quo. Dressing clothes, especially religious ones, is a resistance and a resilience exercise in defense of keeping a personal freedom space which is intended to be inaccessible to the States - one of the last bastions of human freedom. This work is part of the author's research on an expanded thematic which is focused on the recognition of law as an integrated and inseparable part of history, of relations between children, families, society, school, religion and State, and above all, the legitimation of human freedom as an essential element of states that are built under the aegis of a constitutional democracy.

\section{Keywords}

Authoritarianism; Clothes; France; Germany; Individual and religious freedom; Islamic headscarf; Rule of Law; Turkey.

\section{Sumário}

1. Introdução; 2. Turquia; 3. França; 4. Alemanha; 5. Análise Comparativa; 6. Considerações Finais

\footnotetext{
"Temos o direito de ser iguais quando a nossa diferença nos inferioriza; e temos o direito de ser diferentes quando a nossa igualdade nos descaracteriza". (Boaventura de Souza Santos).
}

\section{Introdução}

Em 1930, Noel Rosa estourou nas rádios com a canção Com que roupa. Reza a lenda que a inspiração para a música nasceu de um evento corriqueiro. Preocupada com o filho que saia todas as noites, a mãe escondeu as roupas mais aprumadas de Noel, que ficou se perguntando pela casa com que roupa iria sair. Sem encontrá-las, decidiu abrir mão da noitada. O anseio pela vida noturna naquele dia não superou a vaidade: sem a peça adequada, não seria possível Noel apresentar-se à sociedade.

O personagem de Peter O'Toole, no filme Lawrance da Arábia (1962), consagra-se junto à tribo de beduínos quando retorna de uma missão de salvamento quase impossível. Diante da coragem e do sucesso da empreitada, seu colega harati joga sua farda britânica no fogo e dá a ele uma túnica, uma cafia e o kirpan. A cena é marcante e consagra a 
aceitação do estrangeiro como um verdadeiro membro da respectiva comunidade beduína.

No ano de 2001, a BBC Two lançou o programa What not to wear ${ }^{2}$, sucesso de público e crítica, posteriormente replicado para os Estados Unidos, e embrião de diversos do gênero, com a proposta de auxiliar homens e mulheres a se vestirem "adequadamente". A primeira impressão pode parecer que se trata de mais um reality show superficial. Mas a cada episódio, o que se tem é o equivalente a um experimento científico. Todas as pessoas selecionadas passam por um processo psicológico de autoanálise, com momentos de crises e frustração. Mesmo diante da possibilidade de adquirirem um guarda roupa inteiro novo, todos demonstram apego a determinados itens e a relutância em adotar um modo estilo de vestimenta. Apenas a proposta de mudança no estilo de se vestir provoca uma epifania singular.

Seja na ficção, seja na realidade, parece difícil distinguir o ser humano e a sua vestimenta, na condição de sujeito e objeto. As narrativas acima descritas ilustram o imbricamento existente entre o indivíduo e a sua indumentária e a formação da personalidade a partir dessa união. As características únicas são projetadas na sua forma de se apresentar ao mundo e tal sujeito passa a se identificar com o personagem criado, de tal maneira que não pode jamais voltar-se para os demais como antes. Muda-se por dentro, muda-se por fora, em um ciclo de construção de quem se é e de reconstrução de quem se pretende ser.

Lars Svendsen, filósofo norueguês, autor da obra Moda - Uma Filosofia, nesta mesma direção, relaciona o papel do vestuário com a formação da identidade do ser humano:

Como Simmel enfatizou em Filosofia da Moda, há um vínculo entre moda e identidade. (...) As roupas são uma parte vital da construção social do eu. A identidade não é mais fornecida apenas por uma tradição, é também algo que temos de escolher em virtude do fato de sermos consumidores. A moda não diz respeito apenas à diferenciação de classes, como afirmaram análises sociológicas clássicas de Veblen a Bourdieu, mas está relacionada à expressão de nossa individualidade. O vestuário é parte do indivíduo, não algo externo à identidade pessoal. A filósofa Hélène Cixous enfatiza, por

2 Informação disponível em: https://en.wikipedia.org/wiki/What_Not_to_Wear_(UK_TV_series), com acesso em 15/01/2017.

Revista Publicum

Rio de Janeiro, v.2, n. 2, 2016, p. 254-323

http://www.e-publicacoes.uerj.br/index.php/publicum

DOI: $10.12957 /$ publicum.2016.26368 
exemplo, que as roupas não são principalmente um escudo para o corpo, funcionando antes como uma extensão dele. Todos nós temos de expressar de alguma maneira quem somos através de nossa aparência visual. ${ }^{3}$ Grifou-se.

É possível, portanto, que algo aparentemente superficial seja em última análise a projeção do espírito de cada ser humano? Ou ainda: um grupo pode ver na forma de se vestir uma prática comunitária?

Se a ideia desenvolvida linhas acima estiver correta, de que a roupa e seus acessórios não são meros objetos, mas uma projeção existencial do ser humano, capaz de representar o seu espírito, sua personalidade e suas crenças, invariavelmente chegaremos à conclusão de que qualquer tipo de restrição ao uso de determinada vestimenta consistirá em uma violação à liberdade de autocompreensão e de identidade e, portanto, à violação a um direito fundamental. Vale dizer, o mesmo que impor ao sujeito o ônus de conviver em sociedade como se um terceiro fosse.

Muito embora esta conclusão pareça em um primeiro momento um tanto quanto óbvia, fato é que temos visto, ao longo dos séculos, poderes constituídos demasiadamente preocupados com o que tem entrado e saído do armário das pessoas, em especial, roupas e acessórios que desvirtuam do perfil social idealizado pelo status quo.

A história nos revela que, desde o século XIII, líderes europeus estiveram demasiadamente absorvidos com códigos de conduta voltados à determinação da correta vestimenta. Dessa preocupação nasceram as chamadas Leis Suntuárias ${ }^{4}$. A historiadora italiana Daniela Calanca esclarece que entre os séculos XIII e XVII foram editados em França diversos decretos que estipulavam normas de conduta com relação ao vestuário, festas, ornamentos, entre outros. A ideia por detrás de tal regulação consistia em impedir que pessoas não pertencentes à aristocracia começassem a utilizar bens de luxo próprios desta camada social e com isso gerassem uma confusão quanto ao seu status. Muitas dessas normas também decorreram da influência da Igreja Católica que via com maus olhos o exagero e a ostentação do vestuário. É possível identificar nessas leis uma espécie

${ }^{3}$ SVENDSEN, Lars. Moda: uma filosofia. Rio de Janeiro: Zahar. 2010. Ebook. p. 13.

4 "Em geral, pode-se afirmar que as leis suntuárias refletem a firme vontade de manter os consumos adequados às hierarquias da sociedade, limitando a mobilidade social. Conforme as igrejas cristãs, por exemplo, Deus em pessoa é ofendido por aquelas despesas que também os éditos procuram conter. A inteira ordem do mundo é 'ameaçada' pela falta de moderação, pela corrida ao supérfluo; portanto cada um deve consumir conforme a sua classe. Como na Idade Média, especialmente a partir do século XIII, assiste-se a uma difusão capilar de tais leis na Itália e na Europa (...).". CALANCA, Daniela. História social da moda. 2a Edição. São Paulo: Editora Senac. 2011. p. 46. 
de política econômica e monetária que se preocupava em limitar a excessiva fuga de capital decorrente do consumo de luxo de produtos importados. Ao que tudo indica, o excesso no vestuário era visto ao mesmo tempo como um mal político, social e econômico ${ }^{5}$.

Daniela Calanca, professora de história da indumentária e da moda da Universidade de Bolonha, nos ensina que:

Os legisladores não se referem apenas a caudas e guirlandas, mas arrolam modelos e objetos preciosos muito requintados, como bordados, cintos, botões, pérolas, corais, madrepérolas e esmaltes. Além disso, diferentemente da normativa do século XIII, que recomendava a todos os cidadãos a modéstia e vetava os desperdícios, os múltiplos éditos do século XIV têm como traço comum a identificação daqueles que estão exonerados de tais restrições. ${ }^{6}$

Também, nesse sentido, é a lição do Professor da Universidade de Paris I, Daniel Roche:

Os autores das leis suntuárias sonhavam com uma hierarquização têxtil perfeitamente visível. Isso se evidenciava no cerimonial do judiciário. Na Câmara de Contas, apenas os presidentes desfrutavam do brilho dos veludos de seda, os mestres e funcionários do rei usavam cetins brilhantes, os corretores trajavam damasco, enquanto os auditores e escrivães tinham de se contentar com tafetás mais modestos. $^{7}$

A Igreja Católica no final do século XVII vivenciou uma séria crise institucional em França, em razão de um hábito considerado contrário à boa ética cristã: o uso de perucas. Jean-Baptiste Thiers, clérigo de Champrond e de Vibraque, elaborou, em 1736, obra intitulada Histoire des perruques ou l'on fait voir leur origine, leur usage, leur forme, leur abus et l'irregularité de celles des ecclésiastiques, pela qual visava denunciar o uso das malfadadas perucas por todo o clero. Sua indignação era tanta que entendia a luta contra

5 Ibidem. pp. 45-51.

6 Ibidem. p. 47.

${ }^{7}$ ROCHE, Daniel. A cultura das aparências. Uma história da indumentária (séculos XVII-XVIII). São Paulo: Editora Senac. 2007. p. 53. 
essa prática como uma espécie de cruzada contra superstições e costumes de hereges. Na sua visão, tal imperativo decorria diretamente das lições de São Paulo que proibia que os cabelos estivessem cobertos durante as missas. A culpa, contudo, seria da própria Igreja que, ao invés de fazer valer as suas normas, permitia as mais diferentes modas entre os eclesiásticos. Seria necessária uma perseguição implacável. Tampouco poderiam sobreviver os cabelos artificialmente encaracolados ou tingidos. Era preciso lutar contra os modismos, de modo a reafirmar a supremacia da Igreja e de suas normas ${ }^{8}$.

Com o transcurso do século XX e a chegada do século XXI, deparamo-nos com a sedimentação de uma cultura de massa e de consumo que tem na moda um dos seus principais expoentes. De certo, temos dificuldade de pensar no mundo ocidental em qualquer vestimenta que seja exótica demais, a ponto de provocar conturbação social ou repressão política. Os limites da moda são testados a cada dia. Vestidos feitos de carnes cruas e até mesmo orelhas de coelho compõem o look de celebridades do show business. Não há mais limites para a moda? Será?

Muito embora estejamos vivendo um período de consagração de Estados democráticos de Direito, supostamente vocacionados à preservação de direitos fundamentais e pautados pelo princípio da dignidade da pessoa humana, com compromissos registrados em constituições nacionais, verificamos, por outro lado, que a imposição de restrições quanto à vestimenta ressurge no cenário jurídico com um novo discurso direcionado à restrição da livre expressão de valores e crenças, sobretudo, religiosas. Trata-se de tema que transborda as fronteiras de diversos países e que tem sido objeto de debates acalorados.

Como nos ensina Habermas, vivemos um momento histórico reconhecido como pós-secular 9 . A consciência desta realidade, na visão do autor, deságua na filosofia no pensamento pós-metafísico:

Pelo ângulo de uma retrospectiva histórica, a 'modernização da consciência religiosa' pode ser considerada, de um lado, como tarefa específica da teologia; de outro lado, porém, o pano de fundo da consciência secularista, que é tecido de visões de mundo, é objeto de um debate filosófico permanente, cujo final continua em aberto. A consciência secular que se tem de viver em uma sociedade pós-

${ }^{8}$ CALANCA, Daniela. Op. Cit. p. 69-71. ROCHE, Daniel. Op. Cit. pp. 44-47.

9 HABERMAS, Jürgen. Entre naturalismo e religião. Estudos filosóficos. Rio de Janeiro: Tempo Brasileiro, 2007. 
secular, reflete-se filosoficamente na figura do pensamento pósmetafísico. Ora, tal pensamento não se esgota no trabalho de acentuação da finitude da razão, nem na simples tentativa de jungir uma consciência falibilista e uma orientação veritativa anticética, a qual caracteriza, desde a época de Kant e Peirce, a autocompreensão das modernas ciências experimentais. Já que o pensamento pósmetafísico constitui uma contrapartida secular para a consciência religiosa que se faz reflexiva, delimitando-se em duas direções diferentes: sob premissas agnósticas, ele se abstém de emitir juízos sobre verdades religiosas e insiste (sem intenções polêmicas) em uma delimitação estrita da fé e saber. De outro lado, ele se volta contra uma concepção cientificista da razão e contra a exclusão das doutrinas religiosas da genealogia da razão ${ }^{10}$.

Na obra Entre naturalismo e religião: estudos filosóficos, o autor reflete sobre a necessidade de conciliação do secularismo com as denominações religiosas. A seu ver, não existe outra fórmula senão a promoção da convivência mútua. Sua crítica à visão monolítica do secularismo foi assim descrita:

Enquanto os cidadãos seculares estiverem convencidos de que as tradições religiosas e as comunidades religiosas constituem apenas uma relíquia arcaica de sociedades pré-modernas, mantidas na sociedade atual, eles considerarão a liberdade de religião apenas como uma proteção cultural para espécies naturais em extinção. Na sua visão, a religião não possui mais uma justificação interna. Nesta linha de raciocínio, o próprio princípio da separação entre Igreja e Estado só pode ter o sentido laicista de um indiferentismo preservador. No modo de ler secularista, é possivel prever que as visões de mundo religiosas dissolver-se-ão à luz crítica científica e que as comunidades religiosas sucumbirão às pressões de uma modernização social e cultural, a qual é cada vez mais intensa ${ }^{11}$.

\footnotetext{
10 Ibidem. p. 159.
}

11/bidem. p. 157. 
Para Habermas, no entanto, deparamo-nos com o avanço do Século XXI com a derrocada dessa profecia. A nosso ver, está-se diante do pensamento de um filósofo em sintonia com o seu tempo. A renovação do fenômeno religioso em todo o mundo é um dado real. Vimos, em especial, na América Latina, nas últimas décadas, o crescimento de igrejas evangélicas pentecostais e o rearranjo de forças da Igreja Católica, com a consagração de um Papa argentino. Nessa esteira, a renúncia do Papa Bento XVI e a escolha do pontífice Francisco recolocaram a Igreja Católica nos holofotes internacionais e no cotidiano da população mundial. A mudança de paradigma que acompanha a atuação do Papa Francisco vem fortalecendo a Igreja dia a dia. Sua postura carismática, sua adesão às redes sociais ${ }^{12}$, a promoção dos direitos dos mais pobres e o discurso de conciliação de diversos grupos religiosos reacenderam o espírito da comunidade cristã no mundo. Além disso, outro fenômeno de tem sido responsável pela reabertura do debate entre secularistas e religiosos: o estabelecimento permanente de famílias muçulmanas na Europa após a II Guerra Mundial. A imigração de diversos trabalhadores oriundos da Turquia e do Oriente Médio abriu caminho para a consolidação de comunidades muçulmanas em países europeus e, consequentemente, para a introdução de práticas e costumes religiosos de matriz não cristã.

Will Kymlicka também aborda esta temática sob a ótica do multiculturalismo liberal. A seu ver, o multiculturalismo possui raízes no ethos dos direitos humanos, sendo uma evolução lógica de valores liberais-democráticos. O estado multicultural surgiu, pois, como um caminho possível de fuga de modelos estatais homogeneizadores, permitindo que o conceito de igualdade fosse aos poucos se afastando do sombrio locus da assimilação para se consolidar como uma demanda de integração ${ }^{13}$. Nancy Fraser reflete sobre um novo paradigma de justiça pautado não somente na redistribuição, mas também no reconhecimento. Na sua perspectiva, uma política de reconhecimento teria por objetivo "construir um mundo amigo da diferença, onde a assimilação à maioria ou às normas culturais dominantes não é mais o preço do igual respeito" ${ }^{14}$.

Nesta realidade pós-secular e multicultural, o Ocidente não viveria mais sob o domínio de uma filosofia teocêntrica. Mas isso não significaria a adesão em massa à

\footnotetext{
12 Mensagem do Papa Francisco, via Twitter, em 16/01/2017: “Jamais poderá haver verdadeira paz enquanto existir um único ser humano que é violado na sua identidade pessoal".

${ }^{13}$ KYMLICKA, Will. Multiculturalismo liberal e direitos humanos, In SARMENTO, Daniel; IKAWA, Daniela; e PIOVESAN, Flávia (coordenadores). Igualdade, diferença e direitos humanos. Rio de Janeiro: Editora Lumen Juris, 2010. pp. 217-243.

${ }^{14}$ FRASER, Nancy. Redistribuição, reconhecimento e participação: por uma concepção integrada de justiça. In SARMENTO, Daniel; IKAWA, Daniela; e PIOVESAN, Flávia (coordenadores). Op. Cit. pp. 167-189.
} 
filosofia secularista. Vemos, pois, a construção paulatina de uma liberdade para ser e crer perante um Estado (laico ou não) que deixa de impor aos seus cidadãos a adesão a uma única verdade (religiosa ou laica). E contrariando toda e qualquer previsão apocalíptica dos secularistas, não se está diante do fim das religiões e da sua substituição por um republicanismo cívico pleno. O caminho de liberdade que se busca é aquele capaz de gerar um espaço de conforto para a prática de crenças tidas como minoritárias, reconhecidas como parte integrante de um todo: um mosaico cultural e religioso.

São ideias que ampliam o horizonte da pauta de direitos humanos, trazendo à tona um novo paradoxo - e, por certo, um desafio - para as democracias liberais: o respeito à individualidade integrada. O que se pretende é que essa diferença seja aceita e reconhecida pela comunidade a que pertencemos. Os planos de vida livram-se aos poucos das amarras monolíticas, tornando-se sobremaneira fluidos. O que passa a existir são modos distintos de se viver. $\mathrm{E}$ tudo isso em uma pequena aldeia global: o que se veste em Istambul está na capa dos jornais de Nova York. Chineses formam imensas filas nas lojas da Louis Vuitton em Paris. A música ambiente: um sertanejo universitário do brasileiro Michel Teló.

Nesse cenário globalizado e plural, marcado pela ascensão de Estados democráticos de Direito e pela consagração do constitucionalismo, o que determina afinal a postura adotada pelo Estado quanto ao uso de indumentárias religiosas? A sua aceitação ou a sua restrição varia entre os países? Os modelos de relação entre Estado/religião influenciam na tomada de decisões? Quais os argumentos levantados para justificar tais restrições? Eles se coadunam com os seus respectivos modelos constitucionais? Existem outros fatores políticos e/ou históricos que penetram a discussão? Se ser e vestir-se são parte integrante de uma mesma projeção da personalidade, como seria possível determinar essa dissociação em espaços privados e/ou públicos? Existe, afinal, alguma roupa que emane valores neutros?

Logo, o presente trabalho tem por objetivo aprofundar os estudos neste tópico específico, a saber: a escolha da vestimenta e da aparência como parte da prática religiosa. Para o estudo comparado das políticas adotadas por diferentes Estados, optouse por seguir a orientação metodológica dos trabalhos dos professores Ran Hirschlli5 e

15 Para o autor: "Em tudo isso, uma visão simples, mas poderosa, é muitas vezes esquecida: constituições não se originam nem operam no vácuo. Seu sentido não pode ser significativamente descrito ou explicado em separado das forças sociais, políticas e econômicas, nacionais e internacionais, que formam determinado sistema constitucional. (...) Cultura, economia, estruturas institucionais, poder e estratégia são tão significativos para a compreensão do universo constitucional como as análises jurisprudenciais e perspectivas. Qualquer tentativa de retratar o domínio constitucional como predominantemente legal, em vez de influenciado pela arena social ou 
Vicki C. Jackson ${ }^{16 .}$ Sua principal preocupação: chamar a atenção para a importância de se conjugar a análise do arcabouço jurídico estrangeiro ao contexto histórico e social que lhe é subjacente.

Com efeito, buscou-se uma ampliação das fontes de pesquisa para além daquelas tradicionalmente utilizadas na área do Direito - leis, jurisprudência e doutrina - para abarcar livros e artigos das áreas de moda, sociologia, antropologia e história. Além disso, considerando um dos principais e reconhecidos desafios do estudo do direito constitucional comparado - o idioma estrangeiro - a pesquisa buscou fontes de notícias internacionais, capazes de relatar eventos recentes na história desses países. Nessa esteira, a utilização de notícias de jornais e periódicos online serviu muito bem para o desafio posto: identificar os principais eventos históricos dos países estudados, sobretudo recentes.

Pretendeu-se com isso, como objetivo geral, demonstrar a importância do estudo da história para a análise dos arranjos jurídicos de um país. As leis e normas em geral são parte integrante de um conjunto de acontecimentos que se desenrola em rede. Em suma, são frutos de escolhas políticas e refletem as demandas culturais de um povo em um determinado espaço-tempo. Quando limitamos o estudo do Direito ao tripé clássico norma, jurisprudência e doutrina -, deixamos de lado todo o arcabouço informacional que sustenta faticamente a norma. Perdemos, pois, o raciocínio lógico que conduz a gênese normativa e, com isso, limitamos a nossa análise a uma resposta jurídica empobrecida. Por fim, a análise contextualizada do Direito também amplia a nossa percepção sobre o tempo. Percebemos que muitas ideias se reproduzem na história da humanidade sob a forma de leis que em essência visam o mesmo em diferentes roupagens - limitar a ação e individualidade humanas a padrões socialmente pré-estabelecidos e tidos como

política, estará destinada a gerar uma explicitação fraca, a-histórica, excessivamente doutrinal ou formalista da origem, natureza e consequências do direito constitucional". HIRSCHL, Ran. Editorial In International Journal of Constitutional Law - April 201412 (2) -. p. 1-12.

${ }^{16}$ A classificação descrita por Vicki C. Jackson identifica cinco classes de abordagem metodológica, quais sejam: (i) classificatória; (ii) histórica; (iii) normativa; (iv) funcional; e (v) contextual. O presente trabalho não se limita, contudo, a uma única linha de estudo, uma vez que os argumentos desenvolvidos necessariamente perpassam por uma análise mais abrangente dos diferentes países. Muito embora na teoria seja interessante a compreensão das diferentes abordagens, na prática argumentativa, existe uma espécie de sobreposição dos diferentes caminhos, inevitável ao raciocínio jurídico. De toda forma, tendo por base referida classificação, entende-se que o estudo estará mais próximo das perspectivas: normativa, funcional e contextual. Quanto aos desafios metodológicos muito bem apresentados pela autora, convém destacar a preocupação com a compreensão histórica, social e legal do país analisado. Esta afirma que por trás desses desafios existe sempre o risco da "simplificação". JACKSON, Vicky. Comparative constitutional Law: methodologies (pp. 54-73). In Rosenfeld, Michel; e SAJÓ, András. The Oxford handbook of comparative constitutional Law. Oxford: University Press, 2012 (Ebook). 
"normais". São normas que em geral travam batalhas contra a essência camaleônica do ser humano. A história, a nosso ver, é o registro vivo disso.

De mais a mais, a pesquisa não pretendeu buscar períodos históricos específicos, mas sim utilizar como ponto de partida os momentos históricos de gênese dos países estudados responsáveis por moldar o seu perfil na atualidade: (i) o surgimento da Turquia como Estado-Nação; (ii) a Revolução liberal na França; e (iii) a consagração da Alemanha como uma democracia constitucional, após a II Guerra Mundial, sob a égide da Lei Fundamental de Bonn. Tratou-se aqui de seguir um insight de pesquisa: reconhecer a linha de continuidade entre os momentos de inflexão socioculturais de um povo e a realidade contemporânea. Passado, presente e futuro não são compartimentos estanques, mas uma teia interligada por eventos conexos. Para entender o presente e fazer previsões para o futuro, o que precisamos essencialmente é destrinchar o passado.

Além disso, faz-se mister esclarecer os seguintes critérios pensados para o processo comparativo: (i) escolha de países que apresentam disputas políticas e/ou jurídicas de relevo sobre o tema; e (ii) que se intitulam Estados democráticos de Direito. Um estudo comparativo de "casos semelhantes", pois, que se pretendesse substancial deveria abarcar o máximo de países possíveis, permitindo a identificação de padrões e variáveis que no conjunto fornecessem elementos para a compreensão das relações de causa e efeito do tema em pauta ${ }^{17}$. Noutro giro, a proposta de um artigo é essencialmente limitada. Logo, optou-se pelo estudo de três países, alcançando assim um espectro de análise comparativa suficientemente ampla dentro das balizas possíveis de um ensaio.

O interesse pela Turquia surgiu no ano de 2013, quando foram registradas no país diversas manifestações populares que tomaram as ruas das principais cidades turcas. 0 que era originalmente um protesto contra a reformulação de um parque em Istambul transformou-se em uma onda de críticas populares ao autoritarismo do então Primeiro Ministro Recep Tazip Erdogan ${ }^{18}$. Os holofotes globais movem-se, portanto, para esta região do mundo. E nós, diante deste hiato geográfico e cultural que separa Brasil e Turquia, refletimos: como um país que tem uma maioria muçulmana e uma forte estética

17 Vejamos aqui a lição do professor Alonso Freire: "Muito se tem discutido no campo do direito constitucional comparado sobre os problemas e desafios metodológicos postos aos comparatistas. Um ponto em particular envolve a questão a propósito da necessidade de aplicação de princípios que proporcionem inferências controladas. Entre os vários disponíveis, há o princípio dos 'casos mais semelhantes', o qual é apropriado para o nosso propósito, e sobre o qual segue uma breve explicação. De acordo com esse princípio, os pesquisadores devem comparar dois ou mais cases que sejam, tanto quanto possível, semelhantes para fatores de interesse causal". FREIRE, Alonso. Desbloquando canais de acesso à jurisdição constitucional do STF. In SARMENTO, Daniel (coordenação). Jurisdição constitucional e política. Rio de Janeiro: Forense. 2015. p. 597.

18 Informação disponível em https://en.wikipedia.org/wiki/Gezi_Park_protests, com acesso em $13 / 01 / 2017$. 
de matriz religiosa tem seu Estado estruturado em um laicismo forte? Essa indagação transformou-se em pesquisa e invariavelmente nos levou à compreensão da relação íntima do vestuário da população turca com a formação cultural e política dessa nação. Um sítio único no mundo que por suas fronteiras e suas ideias materializa o encontro das águas do mundo ocidental e oriental - sua análise tornou-se obrigatória.

Na sequência, temos a França, o berço do constitucionalismo liberal da Europa, o país que inaugurou o pilar ideológico e filosófico das democracias modernas e o edifício dogmático dos direitos humanos. Uma nação predominantemente católica que se orgulha de registrar em sua bandeira os valores da igualdade, da liberdade e da fraternidade e que se depara nas últimas décadas com o crescimento de grupos culturais e religiosos minoritários que rejeitam o modelo assimilacionista francês. O debate em torno do uso do véu na França surge, pois, como expressão última de uma tensão social latente. Em 2010, a França aprova lei que veda o uso do véu islâmico integral, proibição que é legitimada em 2014 pelo Tribunal Europeu de Direitos Humanos. Nos anos seguintes, vemos a intensificação dos conflitos jurídicos e sociais em torno desses mesmos temas: indumentárias religiosas, imigração, direito de minorias, acolhimento de refugiados, ataques terroristas e limites da liberdade de expressão. Enfim, os eventos sociais ocorridos nos últimos anos na França colocaram esta nação no epicentro do debate sobre religião, pós-secularismo, multiculturalismo e direitos humanos, tornando-se invariavelmente objeto de observação e de estudos.

Por fim, escolhemos o terceiro país para análise comparativa: a Alemanha. Trata-se de uma nação predominantemente cristã (protestantes e católicos) que teve de se reinventar com o fim da II Guerra Mundial e que ressurge no cenário jurídico, na segunda metade do Século $\mathrm{XX}$, como um relevante produtor de uma dogmática protetiva de direitos fundamentais. Sob a batuta do Tribunal Constitucional Federal, a Alemanha inicia uma trajetória de consolidação do princípio da dignidade da pessoa humana como eixo fundamental do edifício constitucional, ideia esta que se projeta pelos círculos acadêmicos e jurídicos de todo o mundo. Noutro giro, a Alemanha vive também a realidade de acomodação de trabalhadores imigrantes, sobretudo, turcos. E, mais ainda, nos últimos anos, esteve no epicentro do debate sobre a imigração de refugiados da Síria. Consequentemente, diversos casos sobre o uso de indumentária religiosa vêm eclodindo no país, desaguando invariavelmente na corte constitucional. A Alemanha torna-se, portanto, uma peça-chave nesta análise: como um tribunal que se projeta no cenário internacional como essencialmente sensível e protetivo de demandas de direitos fundamentais irá se posicionar sobre o uso da indumentária religiosa? A resposta, pois, da 
corte alemã será referência para o direito constitucional dos Estados democráticos de Direito soerguidos sobre os ensinamentos do constitucionalismo liberal.

O estudo ora proposto, como dito linhas acima, busca ir além dos casos jurisprudenciais, ampliando a sua análise para eventos políticos e sociais encadeados com o cenário jurídico ${ }^{19}$. Considerando que o uso de indumentárias religiosas tem sido objeto de discussão em diversos países que se identificam como Estados democráticos de Direito, além dos supracitados, tais como Suíça, Bélgica, Estados Unidos ${ }^{20}$, Holanda, Bulgária ${ }^{21}$, e inclusive, o Brasil ${ }^{22}$, entende-se que o estudo do direito constitucional comparado nos auxiliará a melhor compreender os argumentos contrários e favoráveis às restrições de natureza indumentário-religiosa e a sua correlação lógica com a proteção dos direitos fundamentais e/ou a preservação de valores comunitários e/ou autoritários.

\section{Turquia}

19 "No entanto, muito da literatura contemporânea (embora certamente não a totalidade) é focada em questões de jurisprudência. Muitas vezes excluídas do discurso canônico, temos outras questões cruciais como o impacto da vida real da jurisprudência constitucional e sua eficácia em lançar sementes de mudança social; como constituições constroem, e não apenas restringem a política (por exemplo, enquadrando os objetivos e interesses em que as pessoas acreditam que possam buscar na política); os atores e os fatores envolvidos na exigência ou na realização da transformação constitucional; o lugar do constitucionalismo, nacional e transnacional, na ordem econômica global emergente, ou mesmo a judicialização crescente da política em todo o mundo e seu impacto na legitimidade dos tribunais e na qualidade de governança democrática em geral ". (...) Chegou o momento de ir além dos relatos seletivos de disposições específicas ou de decisões judiciais (direito constitucional comparado) para uma abordagem mais holística do estudo das constituições em todas as políticas (estudos constitucionais comparativos que valorizam o grande potencial explicativo de descrição profunda das ciências sociais na análise de vários aspectos do universo constitucional)". HIRSCHL, Ran. Op. cit. p. 3 e 11.

${ }^{20}$ ELLIS, R. Georgia lawmaker withdraws bill to restrict burqas. CNN, em 17/11/2016. Informação disponível em: http://edition.cnn.com/2016/11/17/us/burqa-ban-bill-georgia-trnd/, com acesso em $13 / 01 / 2017$.

${ }^{21}$ FOSTER, A. Where in the world are the burka and niqab banned? Express, em 07/12/2016. Informação disponível em: http://www.express.co.uk/news/world/652842/Burka-Niqab-IslamicFace-veil-Ban-UK-Fine-France-Belgium-Netherlands-Europe-Muslim-dress, com acesso em $13 / 01 / 2017$.

22 No segundo semestre do ano de 2014, um aluno de 12 anos foi proibido de frequentar a Escola Municipal Francisco Campos, no bairro do Grajaú, no Município do Rio de Janeiro, por usar vestes típicas da religião do candomblé: roupas brancas e colares (guias). Toda a celeuma durou meses e causou enorme constrangimento ao aluno e sua mãe, os quais tentaram por diversas vezes conversar com a escola, até o momento em que o caso veio a público, com grande repercussão. A solução dada pelo Município foi a transferência do aluno para outra escola da rede pública. MACHADO, M. Auno é barrado em escola municipal do Rio por usar guias de candomblé. G1, em 02/09/2014. Informação disponível em http://g1.globo.com/rio-de-janeiro/noticia/2014/09/alunoe-barrado-em-escola-municipal-do-rio-por-usar-guias-do-candomble.html, com acesso em $13 / 01 / 2017$. 
No caso da Turquia, as questões políticas e jurídicas que se apresentaram ao longo do século XX e XXI envolvendo a codificação do vestuário estão essencialmente conectadas ao processo de formação do Estado nação, forjado em 1923, com a promulgação da primeira Constituição republicana e as subsequentes reformas legais promovidas por Mustafá Kemal Atatürk no período subsequente até o ano de 1935. A expectativa desse líder era a de promover uma mudança na essência e na estrutura da sociedade turca, que a seu ver, estaria submersa na lama de superstições e credos religiosos típicos de povos bárbaros e primitivos. Para garantir que a população viesse a alcançar o nirvana civilizatório existente no mundo ocidental, optou-se por uma política de Estado autoritária e obsessiva de imersão em hábitos seculares civilizados ${ }^{23}$.

O que se pretendia, portanto, era garantir que a nação recém-formada no papel adquirisse um contorno próprio completamente distinto daquele que o precedera, a saber, o Império Otomano. Para criar um novo povo todo o passado deveria ser demolido. Mas o que afinal haveria de tão odioso no modelo de Estado anterior? O que se pretendia abolir?

O Império Otomano representava uma sociedade política e economicamente estagnada incapaz de manter seus territórios e o poderio de outrora. Mas não era propriamente o modelo de governo ou as políticas públicas desgastadas que incomodavam o novo governo republicano, e sim, o modelo social forjado na pluralidade étnico-religiosa que tinha no Islã o seu maior expoente ${ }^{24}$.

Mustafá Kemal Atatürk era o representante de uma nova geração na Turquia que se originara ainda no Império Otomano: os turcos reformistas. Com o advento da Revolução Francesa, a ascensão de Napoleão e a necessidade de fortalecer o Império, o sultão Mahmut II (1809-1839) foi buscar na Europa, particularmente na França, conselheiros que pudessem orientá-lo quanto às reformas capazes de fortalecer o seu poderio militar. Os escritores Nicole e Hugh Pope esclarecem que após essa interação Mahmut II passou a adotar práticas ocidentais no seu dia-a-dia: trocou o turbante pelo fez e aplicou uma lógica ocidental à sua administração. Ele também construiu escolas e deu

23 POPE, Nicole; POPE, Hugh. Turkey unveiled: a history of modern Turkey revised and updated. New York/London: Overlook Duckworth. 2011. pp. 51-68.

${ }^{24} \mathrm{~A}$ tolerância religiosa no Império Otomano era baseada na convivência, em regra, pacífica de diversos grupos étnico-religiosos. A acomodação dos diferentes interesses e práticas religiosas davase por meio do Millet, um sistema que permitia um espaço próprio de regulação a cada um destes segmentos. Ainda, como revelam os escritores Nicole e Hugh Pope, a conquista de Constantinopla, o sultão Mehmet elaborou um decreto solicitando a permanência dos judeus na cidade. Ademais, foi difundido que o seu império estaria de portas abertas para os judeus que quisessem se refugiar de perseguições religiosas, sobretudo, da Espanha. Segundo os autores, os grupos minoritários, não muçulmanos correspondiam à metade da população de Constantinopla até o fim do Império. In Ibidem. p. 27. 
permissões para desenvolvimento da imprensa escrita. O sultão faleceu pouco tempo depois dessas mudanças. Nada obstante, o processo de reformas teve continuidade ao longo de todo o século XIX e ficou conhecido como tanzimat, ou seja, reorganização ${ }^{25}$. Seu ápice ocorreu com a promulgação de uma constituição à moda francesa e a criação de um Parlamento, ainda no ano de $1876^{26}$.

Em 1878, o escritor italiano Edmondo de Amicis $^{27}$ elaborou a seguinte descrição da cidade de Constantinopla:

O progresso dos reformadores, a resistência dos antigos turcos, a incerteza da grande massa que hesita entre os dois extremos, todas as fases da luta entre a nova e a velha Turquia podem ser vistas nas vestimentas. O velho e inflexível turco ainda usa o turbante, o kaftan e os sapatos amarelos de couro marroquinos... O turco reformado usa um longo casaco preto abotoado até o queixo e calças, tendo o fez como único sinal de que ele é turco. O turco com turbante ainda acredita [no céu e no inferno] e vai para casa antes do anoitecer ... os reformadores riem da cara do Profeta, deixam- se fotografar, falam francês e passam a noite no teatro. ${ }^{28}$

A casa parlamentar revelou-se, contudo, demasiadamente crítica das ações do sultão Abdülhamit II (1876-1909). Em 1878, ele acabou por dissolvê-la e revogar a constituição ${ }^{29}$. O sopro de constitucionalismo, contudo, teve consequências: parte dos parlamentares expulsos engajou-se em movimentos políticos clandestinos e revolucionários. Um grupo de exilados em Paris formou o partido de caráter militar Comitê da União e Progresso (doravante, CUP). Jovens oficiais, estudantes e nacionalistas

${ }^{25}$ ANSARY, Tamim. Destiny disrupted: a history of the world through Islamic eyes. New York: Public Affairs. 2009. p. 286.

${ }^{26}$ Ibidem. p. 31.

${ }^{27} \mathrm{O}$ mencionado escritor captou com precisão uma das principais marcas da Turquia: situada entre o Oriente Médio e a Europa, este país é a verdadeira fronteira das duas grandes correntes civilizatórias do mundo atual, o ocidente secular-cristão e o mundo islâmico. Como não podia deixar de ser, toda a sua história esteve permeada pelos influxos do Ocidente e do Oriente. Com efeito, a Turquia é uma nação marcada pela contradição e por sentimentos opostos. Para os países europeus, sua tradição cultural e religiosa é exótica. Para o mundo islâmico, a sua imersão nos valores seculares da tradição ocidental distancia-a da realidade de seus irmãos árabes e persas. Ela é única: um mosaico étnico de todo incomum e ao mesmo tempo representativo da humanidade.

28 POPE, Nicole; POPE, Hugh. Op. Cit. 2011. p. 29.

29 O Império Otomano contraiu nesse período dívidas junto aos países europeus, o que gerou um processo desgastante de negociação e submissão de suas contas e despesas a grupos estrangeiros. Ibidem, p. 32. 
passaram a identificar-se como Young Turks, espécie de movimento que liderou uma primeira revolução, em 1908, a qual teve sucesso em restaurar a constituição ${ }^{30}$.

Dentre os diversos movimentos que surgiam no cenário político, os Young Turks ganharam a simpatia da sociedade grupos com bandeiras nacionalistas e antiimperialistas. Nesse momento, iniciou-se também um processo de radicalização contra as minorias religiosas e étnicas, com destaque para os armenos/cristãos, que foram apontados como detentores de privilégios e responsáveis pela grave crise política e econômica vivenciada pelo Império Otomano ${ }^{31}$. A nação turca deveria representar um só povo, uma só alma. O escritor Tamim Ansary ilustra com precisão as ideias coletivistas que cresciam no seio dos reformistas: "O escritor Ziya Gökalp declarou que, excetuando os heróis e os gênios, os indivíduos não tinham valor. Ele exortou seus colegas turcos a nunca falar de 'direitos'. Não há direitos, disse ele, apenas deveres: o dever de ouvir a voz da nação e cumprir suas exigências" 32 .

Com o fim da Primeira Guerra Mundial, as vitoriosas França e Grã-Bretanha firmaram o Tratado de Sevrés que tinha como objetivo repartir o restante do Império Otomano. Contudo, a demora na sua execução permitiu que grupos militares nacionalistas liderados por Mustafá Kemal se reorganizassem e reconquistassem parte do antigo território otomano, formando a fronteira atual da Turquia e um novo Estado nação, em 1923. Uma constituição foi promulgada, o Parlamento foi restabelecido, o Califado foi extinto e o próprio Atatürk fincou-se como Presidente da República.

A narrativa do escritor Tamim Ansary esclarece que:

A Turquia foi desse modo o primeiro país de maioria muçulmana a se declarar secular e a tornar a separação da política e da religião uma política oficial. Ao rebaixar o Islã, Atatürk precisava, porém, de algum outro princípio para unificar seu novo país, então elaborou uma ideologia que santificava seis 'ismos': nacionalismo, secularismo, reformismo, estadismo, populismo e republicanismo. ${ }^{33}$

\footnotetext{
30 Ibidem. p. 33. aproximadamente 500 mil armenos.

32Ibidem. p. 293.

33 Ibidem. p. 303.

${ }^{31}$ ANSARY, Tamim. Op. Cit. p. 291. Em 1915, neste processo imbricado de fortalecimento nacional, de intolerância étnica e de movimentação bélica, ocorreu um dos maiores genocídios da história. Alguns armenos, de origem cristã, formaram milícias pró-Rússia. Em resposta, o governo otomano elaborou um projeto de destruição de sua população consistente na morte e deportação de 
As reformas iniciadas a partir de 1925 visavam concretizar o plano nacionalista de Atatürk. É interessante notar que muito embora a proposta secularista tenha sido o carrochefe de sua política, a Constituição de 1924 ainda consagrava o Islã formalmente como religião oficial da Turquia ${ }^{34}$. Assim, a leis que vieram a forjar o pacote reformista consistiram em um ajuste muito mais estrito desse programa de governo. Não só houve a reformulação da relação Estado-religião, com a imposição de um governo laico, como foram criadas normas que afastaram por completo os direitos e garantias individuais supostamente consagrados no texto constitucional ${ }^{35}$. Para Atatürk, a nação turca não poderia curvar-se perante o capricho de indivíduos não comprometidos com o programa civilizatório estatal.

Então, um pouco antes de implementar tais reformas Atatürk elabora o "Sermão do Chapéu". Segundo o professor Yasemin Doĝaner:

Ele também falou com as pessoas e questionou a situação daqueles que se recusaram a usar chapéu. Disseram-lhe que essas pessoas estavam pacificadas e tiveram que aceitar essa mudança de boa vontade ou não. Mustafá Kemal destacou que a situação deve ser mantida sob controle até que surjam novas gerações ${ }^{36}$.

$\mathrm{Na}$ cidade de Inebolu, em um discurso inflamado, ele indaga à plateia: "o nosso vestuário é nacionalista? São nossas roupas civilizadas e universais?" Então, todos

34 "Artigo 2‥ A religião do Estado turco é o Islã. A língua oficial o turco. A capital do governo situa-se em Ankara". EARLE, Eduard Mead. The new constitution of Turkey. Political Science Quaterly, Volume 40, Issue 1, (Mar. 1925) 73-100. Disponível em <http://genckaya.bilkent.edu.tr/ 1924constitution.pdf>, em 10/09/2014.

35 “Artigo 68. Todos os cidadãos da Turquia são dotados no nascimento de liberdade e de pleno direito ao seu gozo. A liberdade consiste no direito de viver e desfrutar a vida sem ofensa ou dano aos outros. As únicas limitações à liberdade - que de qualquer forma é um dos direitos naturais são as impostas no interesse dos direitos e das liberdades dos outros. Tais limitações à liberdade pessoal apenas devem ser definidas em estrita conformidade com a lei". (...) Artigo 72. A liberdade pessoal não será restringida ou interferida, exceto nos casos previstos em lei. (...) Art. 75. Ninguém pode ser importunado por causa de sua religião, de sua seita, de seu ritual ou de sua condição filosófica, se não perturbar a paz pública ou chocar a decência pública ou que incorra em violação das convenções sociais da lei". EARLE, Eduard Mead. The new constitution of Turkey. Political Science Quaterly, Volume 40, Issue 1, (Mar. 1925) 73-100. Disponível em: <http://genckaya.bilkent.edu.tr/1924constitution.pdf>, em 10/09/2014.

36 DOGAANER, Yasemin. The law on headdress and regulations on dressing in the Turkish modernization (Bilig - Autumn/2009 - n. 51: pp.33-54 - Ahmet Yesevi University Board of Trustees), disponível em: <http://yayinlar.yesevi.edu.tr/files/article/294.pdf>. Acesso em 25/09/2014. p. 36

Revista Publicum

Rio de Janeiro, v.2, n. 2, 2016, p. 254-323

http://www.e-publicacoes.uerj.br/index.php/publicum

DOI: $10.12957 /$ publicum.2016.26368 
respondem - "não, não", "Nós temos que usar sapatos Oxford, ou botas de cano alto, e calças, casacos, camisas, gravatas, colarinhos, jaquetas, e naturalmente, chapéus" 37.

Logo, o Conselho de Ministros aprova em setembro de 1925 a Resolução n. 2134, determinando aos servidores públicos civis o uso de roupas e chapéus ocidentais. Na sequência, a Turquia aprova a Lei do chapéu - Lei n. 671 (25/11/1925), proibindo a população de usar qualquer outro tipo de chapéu que não o modelo ocidental ${ }^{38}$ :

Artigo 1, os membros da Grande Assembleia Nacional da Turquia, bem como os funcionários públicos e os funcionários das administrações gerais, especiais e regionais, e todas as formas de instituições, são obrigados a usar o chapéu que a nação turca está usando. A cobertura da cabeça usual para a nação turca é o chapéu e o governo proíbe a continuação de qualquer hábito em contradição a este.

Para garantir a coercitividade da medida, estabeleceu-se também a criminalização da referida conduta, por meio do art. 222 do Código Penal, que assim dispõe:

Artigo 222 - (1) As pessoas que agirem em contrário às restrições e às obrigações estabelecidas na Lei N. 671 e datado de 25.11.1925 estipulando o Uso de Chapéu, e a Lei N. 1353 de 1.11.1928 relativa ao Reconhecimento e Aplicação do Alfabeto Turco serão punidas com pena de prisão de dois meses a seis meses.

A professora Yasemin Doğaner afirma que durante o processo legislativo que deu vida à referida lei, Nureddin Pacha, representante da cidade de Bursa, apresentou argumentos no sentido de que a Lei do chapéu violava a Constituição. Em resposta, o

37 GENÇ, Kaya. Turkey's glorious hat revolution (Artigo - LARB) Em 11/11/2013. Disponível em: <http://lareviewofbooks.org/essay/turkeys-glorious-hat-revolution\#>, acesso em 25/09/2014.

38 "Antes da promulgação desta lei, algumas disposições foram feitas sobre a vestimenta de vários grupos. Por exemplo, era proibido aos estudantes de Istambul Medresesi usar turbante e kaftan, (Tanin: 7 de março de 1924), e foi decidido providenciar alterações na indumentária de juízes (Hakimiyeti Milliye: 11 de julho de 1924), os chapéus dos policiais foram mudados para os modelos que tinham uma viseira (Cumhuriyet, 16 de julho de 1925), e os chapéus dos soldados foram substituídos por aqueles usados nos exércitos ocidentais. Embora esses regulamentos possam parecer sem importância, constituíram um importante ponto de partida para os passos a serem tomados nos assuntos sérios (Wortham 1930: 170). Na mesma ocasião, a questão chamada 'Serpuş Meselesi' (a questão do chapéu) começou a ser tratada em público e várias opiniões e avaliações foram expressas sobre ela". DOĜANER, Yasemin. Op. Cit. p. 35.

Revista Publicum

Rio de Janeiro, v.2, n. 2, 2016, p. 254-323

http://www.e-publicacoes.uerj.br/index.php/publicum

DOI: $10.12957 /$ publicum.2016.26368 
parlamentar Refik Koraltan rebateu tal proposição, alegando que essa opinião não representava verdadeiramente a população de Bursa, tratando-se de medidas que ao contrário visavam fortalecer a Constituição. O Ministro da Justiça Mahmut Esat Bey, por sua vez, afirmou que não haveria qualquer relação entre a regulação da indumentária da população e os artigos de relevância da Constituição. Foi dito ainda que tudo isso estava sendo feito em benefício da nação. Por fim, outros parlamentares sugeriram "que a adoção da lei buscava a adoção da mentalidade dos grupos que fundaram a Constituição" e "e que não haveria qualquer relação entre roupas e religião" 39.

O processo de ocidentalização e o consequente impacto na escolha do vestuário já estavam sendo objeto de reflexão pela sociedade turca. Atif Hoca, um estudioso islâmico, escreveu um manifesto em 1924, criticando a substituição da vestimenta tradicional pelo padrão europeu. A seu ver, tratava-se de um hábito que contrariava os ensinamentos religiosos.

Após a edição da lei, ocorreram diversos protestos, que culminaram em mortes e prisões. Atif Hoca foi processado duas vezes pelas suas ideias. Na primeira ação, ele foi absolvido, sob a lógica de que não teria violado lei alguma, uma vez que seu manifesto teria sido elaborado antes da Lei do Chapéu. Ocorre que este foi novamente levado a julgamento pelo Tribunal Independente, uma espécie de corte ad hoc, para dissidentes da República. Ali, fora condenado e sentenciado à pena de morte, sendo enforcado em 04/02/1926. Tal medida extrema foi tomada pelo governo, na medida em que tais opositores eram processados não somente com base na referida lei, mas também por crimes de traição e oposição à cúpula do governo ${ }^{40}$.

Em 1934, foi aprovada a Lei n. 2596, voltada à restrição de vestimentas religiosas, sob o argumento de que o Estado laico determinava a separação entre o Estado e a religião. Assim, os clérigos ficaram restritos ao uso de roupas típicas nos ritos religiosos ${ }^{41}$.

39 Ibidem. p. 37.

40 "Os oponentes do chapéu - a maioria dos quais eram constituídos pelos membros das seitas e imãs religiosos - foram julgados pelos Tribunais da Independência e condenados à prisão, ao exílio ou à morte". Ibidem, p. 41. e GENÇ, Kaya. Op. Cit.

${ }^{41}$ Trata-se de restrições que permaneceram vivas no seio social por muito tempo, como forma de garantir a manutenção de valores secularistas. Tanto assim que estas restrições estenderam-se até os dias atuais. Ahmet Arslan e outros praticantes do grupo religioso Aczimendi Tarikatÿ tiveram muitos contratempos quando, em outubro de 1996, promoveram um grande encontro na cidade de Ankara, ocasião em que usavam roupas típicas religiosas, com destaque para o turbante. Em razão de tal evento, foram presos e indiciados perante a Corte de Segurança do Estado turco. Muito embora tenham sido absolvidos das acusações referentes à data do evento religioso, outra celeuma instaurou-se na corte, em janeiro de 1997, quando os acusados foram instados a retirar os seus respectivos turbantes, tendo estes se negado a fazê-lo. Foram, portanto, acusados de violação das Leis 2596 e 671 . Assim, em razão desta desobediência, foram condenados ao pagamento de multas. Uma vez que seus recursos foram negados em todas as instâncias, estes ofereceram demanda 
Note-se que tais leis estavam voltadas, em princípio, para a população masculina e não abarcavam o uso do véu (ou hijab). Muito embora houvesse um processo de ocidentalização em curso, em essência, estava-se diante de uma sociedade patriarcal, a qual identificava o papel feminino com o ambiente privado. Tratava-se de um tema muito delicado. O banimento do uso do véu não passou, pois, pelo processo legislativo, tendo sido determinado por uma circular secreta encaminhada pelo Secretário Geral do Partido Kemalista para as cidades. Assim, elas baniram o uso do véu em decorrência de uma decisão tomada pelo partido político e não pelo Parlamento. A estratégia utilizada no caso da vestimenta feminina foi, portanto, diferente. Houve a criação de uma campanha ideológica voltada ao convencimento do abandono dos véus sem a imposição de uma lei formal $^{42}$. A fórmula incluía ainda a segregação das mulheres islâmicas de prédios públicos e estruturas estatais, fomentando o processo de marginalização desta parcela da população que insistia em preservar seus valores culturais e religiosos.

Com efeito, a sociedade turca passou a conviver com os dois modelos de indumentária feminina: a secularista e a de matriz religiosa ${ }^{43}$. Esse conflito permaneceu latente no cenário político-social, ressurgindo no ano de 1956, com a elaboração de um projeto de lei que propunha o banimento do véu como a consolidação do modelo secularista e civilizatório do governo. Conquanto diversos grupos tenham apoiado a proposta, com um amplo debate, tendo sido realizadas pesquisas de opinião e oferecido

perante a Corte Europeia de Direitos humanos. Assim, em 23/02/2010, a Corte Europeia de Direitos Humanos julgou o caso Ahmet Arslan e outros v. República da Turquia, confirmando o pedido elaborado pelos autores para condenar o Estado turco pela violação do art. 9o da Convenção Europeia de Direitos Humanos, a qual determina liberdade de pensamento, consciência e religião. Informação obtida no site <file:///C:/Users/membro/Downloads/002-1131.pdf>, em 14/01/2017. V. ECtHR decides Arslan v. Turkey, the Aczimendi Case, BYU LAW - International Center for Law and Religious Studies, em fevereiro de 2010. Informação disponível no site: <https://www.iclrs.org/index.php?pageld=8\&linkld=21\&contentld= $1616 \&$ blurbld=790>, com acesso em 14/01/2017.

42 "Sua relutância em regular a vestimenta das mulheres pode ter sido porque as mulheres religiosas não eram politicamente ativas, desempenhavam um papel subserviente na sociedade em geral, ficavam frequentemente fora da esfera pública e não faziam parte de organizações islâmicas que pudessem representar uma ameaça ao caráter autoritário da nova república". PERES, R. A history of the headscarf ban in Turkey, Turkish Review, em 01/10/2012, disponível em: <http://www.turkishreview.org/newsDetail_getNewsByld.action?newsld=223231>, com acesso em 16/09/2014. Registre-se que este link não dá mais acesso ao documento mencionado uma vez que em julho de 2016, o Estado turco encerrou as atividades desse jornal, prendendo diversos jornalistas, ao argumento de conspirarem contra o governo.

43 "Nas décadas de 40 e 50, a elite republicana considerou o véu como uma prática adotada pela mulher rural sem instrução que não tinha 'o conhecimento' nem 'o poder' para removê-lo. Foi aceito como uma questão de educação e subdesenvolvimento [...] no discurso do Estado, e acreditava-se que o véu desapareceria como resultado da educação, urbanização e desenvolvimento que eram os objetivos do projeto de modernização Kemalista". Ibidem.

Revista Publicum

Rio de Janeiro, v.2, n. 2, 2016, p. 254-323

http://www.e-publicacoes.uerj.br/index.php/publicum

DOI: $10.12957 /$ publicum.2016.26368 
apoio econômico para as mulheres que optassem por abandonar o véu, ao final, o Parlamento não aprovou a lei.

Com o processo de imigração para as grandes cidades, em curso nas décadas de 70 e 80, a presença de mulheres muçulmanas com suas respectivas vestimentas passou a ser uma forte realidade nos centros urbanos. Essa nova geração estava buscando algo além: integração política, educacional e social:

Na década de 80, as mulheres muçulmanas religiosas da Turquia começaram a afirmar sua identidade, em contraste com as mulheres tradicionais do campo que portavam o véu e que permaneciam na periferia da esfera pública. Essas mulheres, na maioria, urbanas, começaram a buscar oportunidades de emprego e de educação universitária e reagiram aos anos de estigmatização com uma forma mais ousada de tessetür (cobrir-se) que incluía um lenço na cabeça que cobria o cabelo e o pescoço, bem preso sob o queixo. o bloco secular classificou esse tipo de tessetür como türban (turbante), diferenciando-o do tradicional e não ofensivo lenço de cabeça "usado pelas avós". Eles o encaravam não como um símbolo religioso, mas como uma provocação política. No entanto, todas as pesquisas mostravam exatamente o oposto; as mulheres islâmicas usavam um véu por razões religiosas, porque acreditavam que é recomendado no Alcorão. Isto não quer dizer que os muçulmanos da Turquia, onde vivem os Alevis e outras seitas, sejam um grupo uniforme em suas crenças religiosas ou que não variem em termos de suas interpretações do Alcorão e do grau de sua religiosidade" ${ }^{\prime 44}$.

Além disso, a Revolução Iraniana de 1979 em evidência no sul reacendeu o espírito nacionalista/secularista dos militares. Com efeito, após o golpe de estado levado a cabo no ano de 1980, o uso do véu retornou para o centro do debate público. Em 1981, o Conselho Nacional de Segurança editou um decreto que proibia as estudantes de frequentarem escolas e universidades com o véu ao mesmo tempo em que foi criada a YÖK (o Conselho de Educação Superior) com o propósito de manter as universidades sob o controle do governo.

${ }^{44}$ Ibidem.

Revista Publicum

Rio de Janeiro, v.2, n. 2, 2016, p. 254-323

http://www.e-publicacoes.uerj.br/index.php/publicum

DOI: 10.12957/publicum.2016.26368 
Com o restabelecimento do sistema democrático, a realização de eleições e a vitória do Primeiro Ministro Turgut Özal, no ano de 1983, o YÖK acabou por suavizar a restrição ao uso do véu, permitindo-o desde que apresentasse um estilo "moderno". Nada obstante, as universidades conseguiram burlar tal determinação, mantendo proibições de acordo com as suas respectivas ideologias. Autoridades do Poder Executivo e do Poder Judiciário afirmavam que: (i) as muçulmanas que insistiam em usar o véu estavam defendendo uma agenda política própria contrária àquela imposta pelo estado secularista; e (ii) mereciam ser protegidas contra a exploração de fundamentalistas religiosos ${ }^{45}$.

A discussão em torno do uso do véu gerou uma série de protestos, uma vez que, na prática, pouco havia realmente mudado, mantendo-se um sistema social de exclusão e discriminação das mulheres muçulmanas que mantinham seus valores religiosos intactos e preservavam o uso do véu. Tal celeuma gerou a elaboração de um projeto de lei que permitia a livre escolha de vestimenta pelos estudantes, o qual foi vetado pelo presidente Evran. Em resposta, o Parlamento editou em 1988 outra lei que permitia o uso do véu decorrente da crença religiosa: "Vestidos e trajes modernos são exigidos em salas de aula, laboratórios, clínicas, policlínicas e corredores de instituições de ensino superior. Cabelo e pescoço podem ser cobertos com um lenço başörtüsü ou turbante devido a crenças religiosas" $" 46$.

Com efeito, a polêmica do uso do véu alcançou o Poder Judiciário recebendo um grande revés pelas mãos da Corte Constitucional que, em 1989, afirmou "que o uso de princípios democráticos voltados a desafiar o secularismo seria um abuso do direito à liberdade de religião". Senão, vejamos:

O véu e o estilo particular de roupa que o acompanha que não tenham uma aparência moderna, não é uma exceção, mas uma ferramenta de segregação. ... Esta situação, que é a exibição de uma imagem pré-moderna, é cada vez mais generalizada e isso é inaceitável em termos dos princípios do secularismo, do reformismo e da República. O uso dos princípios democráticos para desafiar o secularismo é abuso da liberdade de religião. (Id., Citando a FN. 55, Anayasa Mahkemesi [Tribunal Constitucional], 07 de março de 1989, Esas No. 1989/1 [Número Base], Karar No. 1989/12 [Número de

\footnotetext{
$45 \mathrm{Ibidem}$
}

${ }^{46}$ Ibidem. 
decisão] (TC Resmi Gazete [Diário Oficial da República da Turquia], 1989, N.. 20216) (Turk.)" 47 .

Desde então, a Turquia vive uma batalha entre o Poder Legislativo e a Corte Constitucional: o Parlamento ao longo dos últimos trinta anos vem propondo leis e/ou emendas constitucionais favoráveis ao uso do véu e, portanto, à liberdade de identidade religiosa, as quais são posteriormente declaradas inconstitucionais pelo Tribunal Constitucional sob o argumento de ferirem o espírito kemalista e, portanto, secularista proposto para o país. A última decisão da Corte nesse sentido remonta ao ano de 2012 e afasta a liberação do uso do véu no campus universitário em razão de lei editada no ano de 2008. Em 2010, após a vitória na sua proposta de referendo para a reforma constitucional, o então primeiro-ministro Erdogan determinou por meio do YÖK o fim do banimento do uso do véu nas universidades.

Em setembro de 2013, novas medidas foram adotadas pelo governo, de modo a garantir que o uso do véu não fosse mais um mecanismo de segregação das mulheres da vida pública. Assim, tal restrição foi afastada permitindo às mulheres frequentar prédios públicos e assumir cargos públicos com exceção do Poder Judiciário, da Polícia e do Serviço Militar.

Eis que em menos de um ano, em 25/06/2014, a Corte Constitucional turca é instada novamente a se manifestar sobre o tema, decidindo pela primeira vez a favor da liberação do uso do véu por advogadas no bojo de seu exercício profissional ${ }^{48}$. A requerente, uma advogada turca, foi impossibilitada pelo tribunal de representar um cliente em audiência, por usar o véu. A decisão realiza, pois, o cotejo entre os fatos e os artigos 9o da Convenção Europeia de Direitos Humanos e os artigos 10 e 24 da Constituição turca, e ao fim, reconhece por maioria que os direitos de liberdade de religião e consciência e o mandamento constitucional que veda a discriminação foram efetivamente violados. Assistimos à mudança de direção de uma Corte que até aquele momento transvestia-se de um bastião do sistema nacional-secularista. Uma abertura sem precedentes na história do Estado turco.

${ }^{47}$ Turkey: Constitutional Court annuls 2008 law that had lifted ban on wearing headscarves at Universities. Library of Congress, em 03/12/2012. Informação obtida no site da Biblioteca do Congresso americano, a saber, http://www.loc.gov/lawweb/servlet/lloc_news?disp3_|205403419_text, por meio do projeto Global Legal Monitor, com acesso em 16/01/2017.

${ }^{48}$ Ação n: 2014/256 da Corte Constitucional turca, em Plenário, com data de julgamento, por maioria, em 25/06/2014. Disponível em: http://www.constitutionalcourt.gov.tr/inlinepages/leadingjudgements/IndividualApplication/judgm ent/ 2014-256.pdf, com acesso em 12/11/2016. 
Veja-se, contudo, que aproximadamente dois anos depois desta decisão, o cenário político da Turquia sofre uma reviravolta com o golpe militar-secular fracassado e a sobreposição de um contragolpe pelo hoje Presidente Recep Erdogan. Tais eventos mudaram por completo o cenário político e jurídico turco com a prisão de Ministros da Corte Constitucional, restando incerto até o momento se será capaz de seguir um caminho de independência e de promoção do multiculturalismo.

Ato contínuo ao contragolpe, no dia 27 de agosto de 2016, o governo da Turquia publicou no seu Diário Oficial (Official Gazette) regulamento permitindo o uso do véu para as mulheres integrantes da força policial desde que ele fosse da mesma cor dos uniformes e sem qualquer estampa. Destaque-se que essa medida é mais um movimento de ampliação da liberdade do uso do véu na Turquia capitaneada pelo Presidente Erdogan. Trata-se de tentativa de consolidar uma pauta ideológica alinhada com o conservadorismo religioso que tenta de todas as formas (inclusive com a reorganização estatal para um modelo disruptivo do Estado democrático de Direito) se sobrepor a pautas secularistas impostas por governos anteriores de matriz militar ${ }^{49}$. Em suma, este é o cenário turco.

\section{França}

Apesar de a França ser considerada o berço da moda no mundo e de ter sido palco de diversos casos envolvendo o regramento do vestuário nos séculos XVII e XVIII, durante muitos anos o Estado francês esteve alheio à indumentária de sua população. Tudo mudou, contudo, no ano de 1989, momento em que se deu o primeiro debate sobre o uso do véu pelas crianças e adolescentes muçulmanas nas escolas sob o argumento da proteção da laïcité francesa.

Diferentemente da Turquia, a discussão sobre o reconhecimento do uso do véu como um fenômeno religioso no espaço público não está totalmente ligada ao

\footnotetext{
${ }^{49}$ Note-se que as notícias que abordam o tema não indicam a natureza jurídica dessa novel regulação, limitando-se a afirmar que em 27 de agosto de 2016, no Diário Oficial da Turquia (Official Gazette), foi registrada a permissão do uso do véu por policiais mulheres, desde que em harmonia com o uniforme oficial. V. Turkey allows policewomen to wear Muslim headscarf, BBC News, em 27/08/2016. Informação disponível em: http://www.bbc.com/news/world-europe-37205850,; Turkey allows policewomen to wear headscarves. Aljazeera, em 28/08/2016. Informação disponível em: $\quad$ http://www.aljazeera.com/news/2016/08/turkey-policewomen-wear-headscarves160827134711461.html; Turkey allows female police officers to wear headscarf. The new arab, em 28/08/2016. Informação disponivel em: <https://www.alaraby.co.uk/english/news/2016/8/28/turkey-allows-female-police-officers-to-wearheadscarf>, Turkey permits Muslim police women to wear headscarf. $D W$, sem data. Informação disponivel em: <http://www.dw.com/en/turkey-permits-muslim-police-women-to-wearheadscarf/a-19508791>; todos com acesso em 12/11/2016.
} 
republicanismo cívico e o surgimento de seu Estado-nação. Essa é apenas uma parte da história; a outra parte está intimamente conectada aos eventos políticos e sociais ocorridos no país ao longo do século $\mathrm{XX}$, sobretudo, o fenômeno migratório de diversos trabalhadores oriundos de países islâmicos, a consolidação subsequente de suas famílias e a ampliação do espectro cultural e religioso, em um espaço outrora acomodado pelo secularismo e doutrinas cristã $\mathrm{s}^{50}$.

A revolução francesa de 1789 foi inegavelmente um grande ponto de inflexão do Estado francês. Muito embora a França tenha nesses mais de duzentos anos vivenciado grandes transformações, existindo sob a égide da Quinta República, fato é que o sentimento nacionalista de unidade cultural e republicanismo cívico forjado naquele momento da história, e notoriamente consolidado por Jean-Jacques Rousseau na obra $O$ contrato social, moldou a compreensão do Estado voltado à persecução de um bem público equivalente à vontade geral da população ${ }^{51}$.

Por certo, diversos filósofos iluministas foram responsáveis por criar a ideologia fomentadora dos movimentos de ruptura com o Antigo Regime. Contudo, é inegável a influência preponderante de Jean-Jaques Rousseau e de sua obra o Contrato Social na formação do Estado francês. Assim, ele nasce sob pilares antagônicos: por um lado, elabora-se a notável Declaração dos Direitos do Homem e do Cidadão com a consagração de direitos humanos como a liberdade e a igualdade, sobretudo, as liberdades de expressão, de associação, e religiosa; por outro, o Estado ressurge como o verdadeiro e único representante da população, o qual será guiado pela vontade da maioria de seus cidadãos, tal qual estabelecido em um fictício contrato social.

Esta combinação de consagração de liberdades com dirigismo estatal tornou-se uma marca do Estado francês que ao longo do tempo foi revelando, a bem da verdade, um modelo autoritário de conformação social direcionado à uniformização da sociedade e à construção de um laicismo impregnado por valores estatizantes.

Logo, a boa convivência na França exigiria de seus cidadãos e eventuais estrangeiros que se moldassem aos estilos de vida, política e cultura franceses. Não se trata de reconhecer as diferenças para a conformação de uma sociedade plural e

50 V. BOWEN, John R. Why the French don't like headscarves: islam, the state and public space. Princeton and Oxford: Princeton University Press. 2007; e FETZER, Joel S. e SOPER. J. Christopher. Muslims and the State in Britain, France and Germany. Cambridge: University Press. 2005.

51 V. BOWEN, John R. Op. cit. pp. 11-15.

Revista Publicum

Rio de Janeiro, v.2, n. 2, 2016, p. 254-323

http://www.e-publicacoes.uerj.br/index.php/publicum

DOI: $10.12957 /$ publicum.2016.26368 
multicultural. Ao revés, trata-se de garantir oportunidades para que se tornem "verdadeiros franceses" 52 .

Noutro giro, a aversão do Estado para com a Igreja Católica detentora de inúmeros privilégios e historicamente responsável pela formação educacional fomenta a solidificação de um princípio de laïcité. Vale dizer, o Estado estaria proibido de imiscuir-se em assuntos de cunho religioso ao mesmo tempo em que tais manifestações deveriam restringir-se à esfera privada distantes da esfera pública.

O antropologista John F. Bowen nos esclarece a partir de entrevistas realizadas com autoridades do governo francês o sentido do laicismo para acadêmicos e políticos na França, com destaque, para a percepção da filósofa política Blandine Kriegel, à época diretora do Alto Conselho de Integração:

Em resposta às minhas perguntas em outubro de 2003 sobre os muçulmanos na França, ela enfatizou a abordagem francesa distinta para a sociedade. "Defendemos fortemente princípio da laïcité. Temos que nos colocar no espaço público, abstraindo nossas características individuais, de onde viemos e nossas raízes. Esta é a ideia do contrato social". Embora a defensora da ideia de Rousseau de que os cidadãos devem supostamente concordar, no contrato social, a respeitar os princípios gerais, a senhora Kriegel admitiu que os críticos de Rousseau estão corretos em observar que os indivíduos não se reúnem para fazer tal acordo; eles vêm com as suas tradições e suas histórias particulares. "Tudo isso é verdade", ela disse, "mas aqui na França cada indivíduo tem de se abstrair de tais tradições e aceitar a transferência de certos direitos à Lei. Esse é o contrato: passamos do pluralismo à unidade mediante consentimento ». (...) Por fim, ela me explicou de que forma a laïcité não era igual a ideia da liberdade de religião "anglo-saxão". No pensamento anglo-saxão,

52 "De acordo com a forma republicana de pensar, viver juntos em uma sociedade exige acordo sobre valores básicos. (...) Isso significa aderir a uma determinada linha de filosofia política, aquela que enfatiza interesses gerais e valores comuns em detrimento dos interesses individuais e do pluralismo. Essa filosofia é próxima a de Jean-Jacques Rousseau. Ela exige que o Estado construa instituições e políticas designadas a integrar os recém-nascidos e recém-chegados na sociedade francesa, ensinando-lhes certas maneiras de agir e pensar. Se a sociedade tiver os mecanismos adequados para integrar as pessoas, para transformá-las em cidadãos, então o Estado poderá ser bastante generoso no acolhimento de imigrantes, estendendo fronteiras, inclusive concebendo um Império Europeu ou transoceânico. Mas esses mecanismos exigem que os imigrantes assumam os valores e os comportamentos que demonstrem que eles se tornaram franceses". BOWEN, John R. Op. Cit. p. 11. (Grifou-se). 
em Locke ou Spinoza, é o indivíduo concreto que tem direitos; a liberdade de consciência é o fundamento. Em nossa tradição, essas liberdades são garantidas por meio do poder político que garante um espaço público que é neutro em relação à religião". (...) "A escola pública é parte do público porque é onde a educação cívica acontece. Assim é a administração pública. Nunca haverá funcionários públicos Sikhs na França. ${ }^{53}$

Com efeito, a laïcité e o "espírito do republicano cívico" são trazidos à baila como argumentos estruturantes da proibição do uso dos véus nas escolas. Se por um lado o Estado francês pretende que as escolas sejam o espaço central e público de formação do modelo de cidadão francês, por outro, a presença do véu indica a resistência a esse processo de aculturamento e a insistência na percepção do ser humano como dotado de singularidades. Essa presença, portanto, é vista como uma ameaça ao modelo republicano laico. Logo, ela necessita de domesticação pelo Estado.

O citado autor John F. Bowen nos revela, contudo, que outros fatores foram determinantes para a mudança de postura da França quanto ao uso do véu nas escolas, tais como a autoimagem dos franceses como povo colonizador e demandas de caráter social evidenciadas por períodos de crise econômica.

Em suma, esse autor defende que o argumento em prol da laïcité por si só não é suficiente para compreender o fenômeno de restrições à liberdade religiosa imposta aos muçulmanos e cristalizada na proibição do uso do véu nas escolas francesas. Isso porque a estrutura da laïcité consolidado em lei, no ano de 1905, desde o seu início sofreu alterações diante das necessidades de natureza política.

Inicialmente rejeitada pela Igreja Católica, ante a sua proposta radical de total marginalização do fenômeno religioso à esfera privada, ela foi ao longo dos anos sendo objeto de negociação entre Igreja e Estado, até a sua acomodação em 1924. Isto significa, portanto, que alterações legislativas, regulamentos e decisões judiciais permitiram, ao longo dos anos, um processo de suavização do princípio da laicidade de modo que este se moldasse com práticas e instituições religiosas as quais também são parte da cultura e da realidade dos franceses ${ }^{54}$.

\footnotetext{
53 Ibidem. p.14.

54"O status quo parece assim refletir um equilíbrio social e político entre os interesses da Igreja e os da República no que se refere a escolas. $O$ atual regime de laïcité parece ter surgido para incluir uma intensa atividade governamental em benefício de certas religiões". Ibidem. p. 27. 
Mesmo a proibição de financiamento de cultos e prédios religiosos foi de certa forma burlada com a opção pela criação em paralelo de associações culturais e entidades filantrópicas de matriz religiosa que passaram a receber aportes do governo francês. A preocupação com o controle das atividades religiosas acabou por fomentar o que a lei em sua essência e espírito visava extingui: a participação financeira do Estado no dia-a-dia das instituições religiosas. Senão, vejamos:

A lei de 1905 passou a considerar a religião como parte da sociedade civil, e nesse sentido marcou um momento da história francesa de regulamentações religiosas que foi particularmente liberal, no sentido europeu. Porém, a Igreja se recusou a aceitar tal lei, e em 1907-1908, a França promulgou novas leis transferindo a propriedade de prédios de igrejas para os governos das cidades, com exceção das catedrais, que seguiram como propriedade do Estado. Tal dispositivo era aplicável somente a prédios já existentes, o que significa que, atualmente, o governo subsidia a religião Católica muito mais do que outras religiões. A vasta maioria dos prédios da Igreja Católica é subsidiada pelo Estado ou pelos governos municipais, considerando que o mesmo se aplica somente a cerca de metade das igrejas protestantes e dez por cento dos templos judaicos na França. ${ }^{55}$

Assim, se o princípio da laicidade vem sofrendo acomodações necessárias à convivência sadia entre Estado e religião, por que a discussão sobre o uso do véu pelas estudantes muçulmanas continua sendo uma grande polêmica? Além disso, se a relação entre os franceses e muçulmanos remonta o início do século XIX, por que, afinal, esta questão veio à tona apenas em 1989? Sobre o tema, convém tecer as seguintes considerações.

Em 1830, a Argélia tornara-se colônia francesa e, a partir de 1871, passou a ser considerada parte integrante da França. A sua dominação estendeu-se até 1962, quando, após aproximadamente 08 anos de conflitos, a Argélia restaura a sua independência política ${ }^{56}$. Tunísia e Marrocos, por sua vez, consistiam em protetorados franceses. 0

55 Locit.

56 "O discurso oficial não gosta de dar nome às coisas. Entre 1ำ de novembro de 1954 e 19 de março de 1962, 2,7 milhões de soldados partiram para a Argélia. Morreram 25 mil, em combate ou por acidente (principalmente manejando armas). Um milhão de homens foi hospitalizado, 250 mil ficaram feridos ou gravemente doentes, 80 mil receberam pensão de invalidez (é um número baixo,

Revista Publicum

Rio de Janeiro, v.2, n. 2, 2016, p. 254-323

http://www.e-publicacoes.uerj.br/index.php/publicum

DOI: $10.12957 /$ publicum.2016.26368 
primeiro esteve sob o poderio indireto dos franceses de 1881 a 1956 e o segundo, de 1912 a 1956.

A relação da França com o mundo islâmico colonizado indica, contudo, um sentimento real de superioridade por parte dos franceses. O Code de l'Indigénat ou Indigenato estabelecido inicialmente na Argélia e posteriormente expandido para as demais colônias do Império francês é um exemplo concreto disso. Os franceses construíram nas suas colônias uma ordem social estratificada, estabelecendo diferentes regimes jurídicos para diferentes classes de seres humanos, tendo como critério essencial para essa divisão a sua origem étnico-cultural. Os colonizadores franceses foram classificados como cidadãos in totum com acesso às instituições sociais e políticas francesas, ao passo que os muçulmanos colonizados nativos estariam sujeitos a um regime jurídico diferenciado, de cidadania parcial, o qual incluía regras de punição, tributação especial e trabalho forçado ${ }^{57.58}$

Muito embora a declaração de direitos do homem e do cidadão propusesse a igualdade entre os povos, na prática, na colônia e nos protetorados, o sistema imposto era de segregação para os nativos, os quais possuíam um status diferenciado dos cidadãos franceses. O escritor Tamim Ansary nos traz a seguinte perspectiva:

Durante o século seguinte, a comunidade francesa na Argélia chegou a setecentos mil cidadãos franceses. Eles chegaram a deter a maioria do território e consideravam-se algerianos nativos, já que haviam nascido em solo algeriano e muitos eram filhos de pais nascidos lá. Inconvenientemente, cerca de cinco milhões de árabes por acaso moravam lá também e ninguém conseguia entender de onde eles vieram ou o que eles estavam fazendo lá. Eles não pareciam ter

pois diversos problemas psiquiátricos se revelaram meses depois do retorno à vida civil). Juridicamente, essa guerra não existe. São operações para 'manter a ordem'. Passarão vinte anos até que as pensões deixem de ser consideradas 'por não guerra'. Não é exagero falar em silêncio de uma geração. Os veteranos voltaram em meio à indiferença. Alguns testemunhos. 'Nossos próximos achavam que a guerra, em qualquer estágio que fosse, terminava no mesmo dia em que voltávamos para a casa. Ainda era frequente dizer que tínhamos prestado nosso serviço na Argélia. Um serviço um pouco prolongado, é só'. 'Era tácito que éramos vítimas da 'guerra suja'. Era um papel que não tinha nada de enaltecedor. De qualquer maneira, para que contar o que tínhamos vivido, já que ninguém nos escutava? Da mesma forma que nós, que tínhamos vontade de falar de outra coisa'.". VICENT, Gérard. Guerras ditas, guerras silenciadas e o enigma identitário. In ARIÈS, Philippe; e DUBY, Georges (Dir. coleção); e PROST, Antoine; e VICENT, Gérard (org.). História da vida privada 5: da primeira guerra a nossos dias. São Paulo: Companhia das Letras, 2009. p. 193.

57 V. BOWEN, John R. Op. Cit. pp. 34-36.

58 Informação disponível em <https://en.wikipedia.org/wiki/Indig\%C3\%A9nat>, com acesso em $14 / 01 / 2017$. 
qualquer função e, quais fossem os seus meios de sobrevivência, tratava-se de uma economia completamente separada da economia que envolvia os algerianos de origem francesa. Por volta de 1850, os europeus controlavam todas as partes do mundo e aquilo que à época era chamado de "Dar al-Islam". Eles viviam nestes países como uma classe alta, eles os comandavam diretamente ou decidiam quem os comandaria, eles controlavam os recursos, eles ditavam as políticas, e eles restringiam o dia a dia de seu povo. ${ }^{59}$

A estreita convivência entre franceses e muçulmanos permitiu que a França fomentasse a imigração para o seu território, inicialmente, durante a Primeira Guerra Mundial, e em seguida, no período pós Segunda Guerra Mundial, com o objetivo de que suprissem a demanda por mão de obra. A maioria dos imigrantes consistia em homens trabalhadores que buscavam na Europa melhores salários e a oportunidade de garantir o sustento de seus familiares em seus países de origem. Tal proposta foi extremamente bem-sucedida até a crise da década de 70 e o início de um período de recessão. 0 governo estimava que com a diminuição da oferta de emprego, muitos retornariam aos seus países de origem. Contudo, não foi bem isso o que aconteceu. Temerosos pela crescente imposição de barreiras migratórias, muitos desses trabalhadores incentivaram a imigração de seus familiares, o que acabou por consolidar a formação de uma nova comunidade muçulmana na França ${ }^{60}$.

Logo, a formação da comunidade muçulmana na França deu-se em etapas de acordo com os interesses da própria nação que, ora buscou expandir seu domínio territorial e sua zona de influência política e econômica, ora incentivou a migração de trabalhadores estrangeiros para suprir a demanda de mão de obra. Em 1926, quando a França buscava agraciar tais trabalhadores e a sua comunidade, ninguém levantou a bandeira da laïcité para questionar sobre a legalidade da construção da Mesquita de Paris pelo governo francês.

De acordo com Fetzer e Soper, em 1975, a proporção de estrangeiros/descendentes na França era de 10\%, ao passo que no início do ano 2000, esta passou para $20 \%$. Assim, a década de 80 na França ficou marcada por uma crescente

\footnotetext{
59 ANSARY, Tamim. Op. cit. p. 245-246.

60 V. FETZER, Joel S. e SOPER. J. Christopher. Muslims and the State in Britain, France and Germany. Cambridge: University Press. 2005.

Revista Publicum

Rio de Janeiro, v.2, n. 2, 2016, p. 254-323

http://www.e-publicacoes.uerj.br/index.php/publicum

DOI: 10.12957/publicum.2016.26368
} 
onda antimigratória, a qual atribuía aos estrangeiros a responsabilidade pela recessão econômica vivenciada pela nação.

O ano de 1989 ficou marcado, portanto, como o ano da primeira grande polêmica sobre o uso do véu nas escolas francesas, dando origem ao primeiro capítulo do scarf affair ou affaire du foulard. Três estudantes muçulmanas de uma escola pública do subúrbio de Paris foram suspensas por se recusarem a retirar o véu ao entrar na unidade escolar, sob o argumento de violação ao princípio da laicidade. Devido à repercussão do caso, em pouco tempo, as famílias e a escola fizeram um acordo, de modo que as alunas foram autorizadas a usar o véu, desde que o colocassem na altura dos ombros na sala de aula. Nada obstante, o acordo não durou muitos dias, uma vez que as alunas novamente recusaram-se a retirar o véu, o que culminou com a sua expulsão da comunidade escolar $^{61}$.

Os escritores Fetzer e Soper destacam que este foi o estopim para o início de um embate de forças entre defensores de uma "laicidade forte" e de uma "laicidade fraca" para o Estado francês. De um lado a primeira-dama Danielle Mitterrand e o Ministro da Educação propunham o reconhecimento do pluralismo religioso e a negociação com as famílias sem a expulsão das crianças das escolas e, de outro, os sindicatos dos professores e partidos da oposição incentivavam a desobediência civil. Com efeito, o Ministro da Educação solicitou do Conselho de Estado uma consulta para o caso que, em 27/11/1989, proferiu o seguinte entendimento:

Nas instituições educacionais, estudantes usando símbolos (sinais) com o intuito de indicar sua identificação com uma religião (em particular) não é, em geral, incompatível com o princípio de laïcité já que (essa exibição) constitui o exercício da liberdade de expressão da pessoa e o direito de identificar suas crenças religiosas; mas esta liberdade não permite aos estudantes exibir símbolos de vinculação religiosa que, por sua natureza, pelas condições nas quais elas são usadas, individual ou coletivamente, ou pela sua ostentação ou caráter de protesto... perturbem a ordem ou o funcionamento normal dos serviços públicos (Jézéquel 1999:89-90). ${ }^{62}$

\footnotetext{
$61 \mathrm{lbidem}$.

62 Ibidem.

Revista Publicum

Rio de Janeiro, v.2, n. 2, 2016, p. 254-323

http://www.e-publicacoes.uerj.br/index.php/publicum

DOI: 10.12957/publicum.2016.26368
} 
Em 1994, o então Ministro da Educação François Bayrou editou uma circular ministerial complementar à decisão do Conselho de Estado francês pela qual vedava o uso de véus nas escolas públicas por considerá-los ostensivos no ambiente escolar. Com efeito, a questão continuou sendo alvo de polêmica, na medida em que não foi capaz de impedir a manifestação de estudantes que observando a sua crença religiosa prosseguiram no seu intento de frequentar a escola usando o véu.

Desde então, diversos casos foram encaminhados aos tribunais e ao Conselho de Estado francês que, na sua maioria, determinaram a reintegração do aluno à escola ${ }^{63}$. Noutro giro, os sindicatos dos professores iniciaram um processo de repúdio ao uso do véu, o qual culminou em uma série de greves, manifestos e demonstrações em prol de um laicismo forte forjado na compreensão da estrutura escolar francesa uniforme e impermeável ao pluralismo religioso ${ }^{64}$.

Nessa linha, muitos professores justificaram suas medidas repressivas com base em um discurso feminista ou mesmo emancipatório. Alegavam que o uso do véu constitui uma medida repressiva contra as mulheres prejudicial às outras alunas muçulmanas que não desejam seguir este costume e se sentem pressionadas a tanto no ambiente familiar e comunitário. Alguns até mesmo tentam apresentar argumentos de matriz religiosa, afirmando que o uso do véu seria uma interpretação equivocada dos ensinamentos do profeta Maomé. Muitos se engajaram em práticas de convencimento, afirmando para as alunas que caso insistissem em usar o véu estariam sempre lutando contra o sistema e, provavelmente, teriam dificuldade de serem aceitas em cargos públicos, uma vez que no setor público é vedado o uso do véu ${ }^{65}$. Basicamente, os professores assumiram para si a missão de "proteger" os alunos de práticas religiosas comunitárias e familiares.

Na prática, o que se verificou é que o perfil da direção passou a ser determinante para a aceitação das alunas muçulmanas que optavam pelo uso do véu, culminando em

${ }^{63}$ Antes mesmo da edição da mencionado circular, em 1993, o Tribunal Administrativo de d'Orléans reformou a decisão do diretor do Liceu Ronsard in Vendôme, que havia expulsado duas alunas de origem turca pelo uso do hijāb. "Assim sendo, ao final da década de 90, o Conselho havia desenvolvido uma clara e consistente jurisprudência sobre o assunto: as escolas poderiam expulsar alunas que não assistissem a todas as aulas ou se o seu caso gerasse algum tipo de protesto, mas não meramente por utilizarem véus". BOWEN, John R. Op. Cit. p. 91.

${ }^{64}$ Mundo: professores franceses em greve contra os véus. "Professores de uma escola, numa pequena cidade no noroeste da França, entraram em greve contra a permissão do uso de véus islâmicos pelas alunas". A maioria dos setenta professores da escola de Flers, na Normandia, dizem que o uso de tais véus viola uma regulamentação proibindo a exibição clara de símbolos religiosos em escolas do estado. A greve envolve uma garota de doze anos, de origem turca, que fora ordenada por seu pai a usar o véu. O Ministro da Educação da França nomeou um mediador especial após uma série de incidentes similares". BBC News, em 08/01/1999. Informação disponível em: < http://news.bbc.co.uk/2/hi/europe/251112.stm>, com acesso em 16/01/2017.

65 V. BOWEN, John R. Op. Cit. p. 99. 
uma esfera de decisionismo administrativo. Tudo isso ao invés de arrefecer o sentimento religioso da comunidade muçulmana teve o efeito contrário de fomentar a combustão social permeada pelo sentimento de segregação promovido pelo status quo ${ }^{66}$.

$\mathrm{Na}$ sequência, em 1996, a França criou um órgão governamental intitulado “Observatório Internacional de Seitas", cuja nomenclatura passou em 1998 para "Missão Interministerial de Lutas contra as Seitas", "cuja missão seria de encontrar melhores formas de analisar cultos e aprimorar o combate contra os mesmos" ${ }^{67}$. Houve, portanto, um movimento estatal cujo objetivo era repreender o proselitismo de minorias religiosas e demais grupos cuja matriz ideológica pudesse representar uma ameaça à ordem pública francesa.

Tal fenômeno intensificou-se com o evento do ataque terrorista de 11 de setembro de 2001 às torres gêmeas em Nova York. O escritor J. Bower nos revela que, em 2002, um novo evento envolvendo o uso do véu em uma unidade escolar em Paris foi o estopim para a mudança de tom da mediadora do Ministério da Educação Hanifa Chérifi a qual afirmou que em todos esses anos os franceses vêm negligenciando o significado intrínseco do uso do véu, a saber, lembrar as mulheres que a moralidade islâmica impede a convivência comum entre os gêneros masculino e feminino no espaço público, inclusive na escola 68 .

Em 2003, outro caso de repercussão nacional ficou conhecido como "As irmãs Levy". Duas irmãs de origem judaico-muçulmana iniciaram práticas islâmicas por conta própria dentre as quais o uso do véu. Em pouco tempo, elas foram retiradas da classe. Isso gerou uma celeuma interna ante a postura tolerante do diretor, o qual afirmara que as mesmas tinham o direito de descobrirem a si mesmas. Os professores novamente ficaram enfurecidos e elaboraram uma carta aberta afirmando que a expulsão era necessária. As alunas foram expulsas. Na sequência, os alunos da sala de uma das irmãs entraram em greve sob o argumento de que a escola, por outro lado, admitiria alunos com roupas góticas e até o uso de camisas com slogans "Vote no diabo" 69.

Em julho do mesmo ano, o Presidente Jacques Chirac determinou a formação de um grupo de trabalho comandado pelo representante do governo Bernard Stasi com o propósito de avaliar o sentido e o alcance do princípio do laicité, bem como colher

66 Ibidem, pp. 80-95.

${ }^{67}$ O'BRIEN, Robert. The Stasi Report: the report of the committee of reflection on the application of the principle of secularity in the republic. Buffalo, New York: William S. Hein \& Co. Inc., 2005. p. xix.

${ }^{68}$ BOWEN, John R. Op. Cit. p.93.

69 Ibidem. p.111. 
elementos junto à comunidade francesa sobre questões controversas acerca de práticas religiosas e a sua conformação com o modelo de estado francês.

É pertinente ressalvar que o relatório não teve como objetivo o estudo apenas do tópico do uso do véu nas escolas. Nada obstante, as proposições do Relatório Stasi entregue em dezembro de 2003 geraram consequências já no ano de 2004, quando a Assembleia Nacional promoveu a reforma no Código de Educação francês, incluindo norma legal que estabelecia a proibição do uso ostensivo de símbolos e de indumentárias religiosas. O artigo 141-5 anterior à reforma previa que o ensino nas escolas públicas seria confiado a um corpo docente laico. Com a promulgação da Lei 2004-228 de 15 de março de 2004, foi acrescentado o artigo L 141-5-1, o qual estabeleceu a proibição nas escolas, nos colégios e nos liceus o uso de símbolos e de vestimentas pelos alunos que por eles manifestassem ostensivamente uma filiação religiosa. Além disso, a norma previu que antes da instauração de um procedimento disciplinar, as escolas deveriam promover o diálogo com o aluno ${ }^{70}$. Segundo J. Bowen: “Como muitos deputados admitiram durante seus discursos, essa lei pretendia ser 'simbólica': transmitir uma mensagem aos islâmicos, e ao mesmo tempo aos cidadãos franceses, de que a França defende os princípios da laïcité e da igualdade de gênero ${ }^{71}$."

A questão tomou uma proporção inacreditável quando extremistas islâmicos sequestraram dois jornalistas franceses e demandaram a reversão da lei que proibia o uso do véu nas escolas. Muitas alunas sentiram-se culpadas e optaram por dar um passo atrás evitando a construção de uma imagem de aliança com fundamentalistas islâmicos, o que suavizou o debate e ajudou a diminuir o número de casos de embate entre alunos e professores. Noutro giro, a suposta pacificação do tema deu-se em parte pela opção de muitas estudantes em simplesmente não mais aparecer nas escolas. A situação ficou sobremaneira confusa para os estudantes homens integrantes da religião Sikh os quais tinham por prática religiosa o uso do turbante. Muito embora a lei se aplicasse formalmente a eles, como seria possível sustentar o argumento de que o turbante seria um objeto de opressão de gênero e a ação do Estado um levante em prol da sua emancipação?

Em 2010, a França editou a Lei n. 2010-1192, também voltada a regular a indumentária de sua população. De acordo com essa nova normativa ficou proibido na

70 "Artigo L141-5-1 - Nas escolas, nas faculdades e nos liceus públicos, o uso de símbolos ou vestuário pelos quais os alunos manifestem ostensivamente uma identificação religiosa é proibido. O regimento interno determina que a aplicação de um procedimento disciplinar deve ser precedido de um diálogo com o aluno".

${ }^{71}$ BOWEN, John R. Op. Cit. p. 135.

Revista Publicum

Rio de Janeiro, v.2, n. 2, 2016, p. 254-323

http://www.e-publicacoes.uerj.br/index.php/publicum

DOI: $10.12957 /$ publicum.2016.26368 
França o uso de qualquer vestimenta em locais públicos que impeçam a identificação visual do rosto de uma pessoa. Assim, todos os tipos de máscara, touca, burca e niqab passaram a ser ilegais, com exceção de espaços como veículos e locais de culto religioso.

No dia 11/04/2011, uma paquistanesa identificada como S.A.S. ajuizou perante a Corte Europeia de Direitos Humanos ação contra o Estado francês alegando que a mesma teria por hábito usar a burca e o niqab de acordo com a sua convicção religiosa pessoal ${ }^{72}$. Argumentou a autora que o uso de tal vestimenta está associado ao seu sentimento religioso, o que não necessariamente ocorre todos os dias. Quando sai para uma consulta médica ou marca um encontro com amigos tem por hábito sair sem tal vestuário. Nada obstante, durante determinados períodos, como no caso do Ramadã, sente a vontade de usá-la em público como forma de expressar a sua devoção religiosa. Além disso, a requerente afirmou que não insistiria no uso de tais roupas em aeroportos, bancos ou postos de segurança e que concordaria em revelar o rosto quando houvesse a solicitação de qualquer autoridade.

A decisão da Corte Europeia traça um histórico da discussão no governo francês: inicialmente, o Primeiro-Ministro elaborou consulta ao Conselho de Estado, indagando-Ihe sobre a possibilidade de banimento do véu completo em espaços públicos. O Conselho de Estado afirmou que uma lei não poderia estar voltada a um determinado grupo, o que invariavelmente violaria a vida privada e a liberdade religiosa, valores consagrados pela República. Nada obstante, seria possível a edição de uma lei que banisse de forma geral o uso de roupas que cobrissem completamente o rosto com fundamento na segurança e ordem pública.

Curiosamente, na exposição de motivos da referida lei novamente se reitera que o uso do véu completo (burca e niqab), apesar de se tratar de um fenômeno marginal, consistiria numa manifestação religiosa sectária de rejeição aos valores da república. Além disso, o argumento em prol da igualdade de gênero foi novamente trazido à tona. $\mathrm{Na}$ decisão, a Corte Europeia de Direitos Humanos rejeitou os argumentos que sustentavam a desigualdade de gênero e a necessidade de proteção das mulheres por entender que se trata de uma presunção sem correspondente evidência. Também buscou afastar argumentos que dispunham sobre a discriminação quanto a grupos religiosos.

Entretanto, a Corte, em 1 o de julho de 2014, julgou o pedido da parte autora improcedente com fulcro na ideia de que existem condições mínimas de convivência

72 Caso S.A.S. x França - (Ação n. 43835/11), Strasbourg, em 01/07/2014: Disponível em: file:///C:/Users/membro/Downloads/CASE\%200F\%20S.A.S.\%20v.\%20FRANCE.pdf, com acesso em 15/10/2014. 
social (living together), o que deveria ser observado no caso em tela por meio da proibição do uso de roupas que impedissem a interação social em espaços públicos. E que em se tratando de países sustentados pelo processo democrático, o qual por essência promove diferentes modelos de política pública, haveria a necessidade de deferência às escolhas locais. Logo, o pleito foi julgado improcedente sob o argumento de que a lei francesa não violaria os artigos 8으, 9으, 10으, e 14으 da Convenção Europeia de Direitos do Homem.

É importante registrar ainda o histórico de decisões do Conselho de Estado francês sobre o tema. Durante a década de 90, verificou-se como regra a permissão do uso do véu e demais vestimentas de natureza religiosa nas escolas e universidades [ $n^{\circ} 130394$ (02/11/1992); n 170106 (26/07/1996); n 170207 (27/11/1996)]. Contudo, após a elaboração da emenda ao Código de Educação, com a inclusão em lei de provimento que proibia o uso de vestes religiosas "ostensivas", em 2004, o Conselho mudou sua orientação, passando a indeferir os pleitos propostos pelos alunos adeptos de vestimentas com expressão religiosa [ $n^{\circ} 295671$ (05/12/2007); $n^{\circ} 285394$ (05/12/2007); $n^{\circ} 306833$ (10/06/2009); e no 366749 (19/03/2013)]. Vemos, portanto, que o Conselho de Estado francês tem atuado em prol da preservação da lógica estatal em detrimento da preservação de direitos fundamentais.

Estas questões assumiram o palco central do debate nos últimos anos, sobretudo, com a intensificação de atos terroristas em França, com destaque para: (i) o atentado no jornal satírico francês Charlie Hebdu, em 07/01/2015; (ii) o ataque ao mercado Kosher parisiense, em 09/01/2015; (iii) o ataque de hackers a mais de 19.000 websites franceses, em 15/01/2015; (iv) o coordenado ataque em Paris à boate Bataclan, a explosão de bombas do lado de fora do State de France durante um jogo amistoso entre França e Alemanha e uma sequência de tiroteios em restaurantes e bares parisienses, entre os dias 13 e 14/11/2015; e (v) o episódio de Nice em que um terrorista tunisiano jogou um caminhão com diversas armas e explosivos em cima de pedestres, atropelando-os em massa, no dia da comemoração da Queda da Bastilha, em 14/07/2016.

Diante dessa onda de ataques e de crescimento da xenofobia e da islamofobia, algumas cidades francesas imediatamente decidiram por proibir o uso do burkini assim batizado como uma espécie burca-biquíni que cobre todas as partes do corpo da mulher com exceção do rosto. Argumentou-se que o burkini representaria uma ameaça à ordem pública e ao secularismo ou mesmo uma roupa que transmitiria o alinhamento aos movimentos terroristas que declararam guerra contra a França. Com efeito, diversas 
mulheres foram multadas, presas ou advertidas na costa francesa acerca do uso dessa vestimenta ${ }^{73}$.

Não tardou muito para que o debate sobre o uso do burkini chegasse ao Conselho de Estado Francês. Trata-se dos casos de n. 402.742, de 26/08/2016 e de n. 403.578, de 26/09/2016. No primeiro, a Liga de Direitos Humanos da França (LDH) e a Associação de Defesa dos Direitos Humanos - Coletivo contra a islamofobia (ADDH-CCIF) pleitearam a suspensão da execução de um ato normativo da comuna de Villeneuve-Loubet, em Nice, o qual bania das praias da cidade o uso de vestimentas contrárias aos "bons costumes" e à laicité cujo foco era, principalmente, os burkinis. No segundo, a ASSH-CCIF, agora na comuna de Cagnes-Sur-Mer, pleiteava a suspensão de dispositivo que bania o burkini e outras vestimentas similares das praias da região.

Nas duas oportunidades, o Conselho de Estado francês reconheceu o pedido dos autores, ao entender que os atos normativos locais violavam liberdades individuais protegidas pelo art. 34 pela Constituição francesa. Além disso, a corte administrativa reconheceu que tais banimentos seriam também contrários ao artigo 225-1 do Código Penal Francês e ao artigo 2212-1 do Código Geral de Coletividades Territoriais ${ }^{74}$.

Este é, pois, o cenário da França.

\section{Alemanha}

A origem da nação alemã por certo remonta o ano de 1871, quando pela primeira vez houve a sua unificação política e administrativa. Nada obstante, a sociedade alemã tal qual conhecemos construiu suas linhas mestras após a derrota do projeto nazista de Adolf Hitler e o consequente fim da Segunda Guerra Mundial, em 1945. Mais precisamente a elaboração da Lei Fundamental de Bonn em 1949 redirecionou o curso da sua história voltada à reconstrução de um modelo jurídico pautado pela ética dos direitos

73 V. DEARDEN, L. Burkini ban: Why is France arresting Muslim women for wearing full-body swimwear and why are people so angry? Independent, em 24/08/2016. Disponível em: <http://www.independent.co.uk/news/world/europe/burkini-ban-why-is-france-arresting-muslimwomen-for-wearing-full-body-swimwear-and-why-are-people-a7207971.html>, com acesso em $14 / 11 / 2016$.

${ }^{74}$ Conselho de Estado francês, Caso n. 402.742, ECLI:FR:XX:2016:402742.20160826, em 26/08/2016. Disponível

em: <https://www.legifrance.gouv.fr/affichJuriAdmin.do;jsessionid=539CBBF3D85EFA2F067A6D2B26C0 AB27.tpdila21v_1?oldAction=rechJuriAdmin\&idTexte=CETATEXT000033070536\&fastRegld $=4290245$ 26\&fastPos=8>; e Conselho de Estado francês, Caso n. 403.578, ECLI:FR:XX:2016:403578.20160926, em 26/09/2016. Disponível em <https://www.legifrance.gouv.fr/affichJuriAdmin.do?idTexte=CETATEXT000033163065>, com acesso em 12/11/16. 
fundamentais. Com a reunificação, hoje a Alemanha na sua integralidade passou a integrar o grupo dos Estados democráticos de Direito.

Mais do que isso, o Tribunal Constitucional alemão tem assumido posição de destaque ainda na segunda metade do Século XX com decisões voltadas à consagração do princípio da dignidade da pessoa humana como epicentro do ordenamento jurídico e partir da sua capacidade de inspirar e influenciar os demais países na compreensão de um direito constitucional essencialmente protetivo dos direitos fundamentais.

Além disso, o Tribunal também é reconhecido pela construção de uma jurisprudência favorável a uma interpretação mais complexa sobre o alcance e os limites dos direitos fundamentais, os quais formariam uma pauta objetiva de valores a guiar toda a sociedade alemã. Assim, os direitos fundamentais alçaram voo para além da relação cidadão-Estado projetando-se para todo o ordenamento jurídico infraconstitucional, bem como para as demais relações sociais em curso no país.

Em suma, o Estado passou a reconhecer a sua função essencial na promoção de valores albergados na Constituição de modo a torná-los reais no seio da comunidade alemã. O precedente deste modelo é o conhecidíssimo caso Lüth. Nesse julgamento, o Tribunal alemão deparou-se com uma celeuma entre particulares envolvendo ações de boicote de um determinado filme. Erich Lüth iniciou uma série de manifestações contra filmes do cineasta Veit Harlan ante o seu histórico de participação no movimento nazista e produção de filmes depreciativos da comunidade judaica. Em resposta, produtores ajuizaram ação contra Lüth com fulcro no Código Civil. O Tribunal alemão proferiu decisão em prol da liberdade de expressão ao afirmar justamente que o texto constitucional forjado a partir de uma elevada carga axiológica teria a propriedade de irradiar-se para todo o sistema, mesmo em se tratando de relações entre particulares.

Com efeito, o que se nota no caso da Alemanha é que diferentemente da Turquia e da França, o Estado-nação não se conformou a partir de uma pauta republicana obcecada pelo secularismo e/ou pela predominância de valores estatizantes em detrimento dos direitos e sentimentos individuais. Ao revés, a Alemanha apresenta-se no cenário internacional como exemplo de um país compromissado com a garantia e a promoção de direitos fundamentais, sobretudo, a partir da ótica essencial da dignidade da pessoa humana.

Logo, o cenário jurídico e social no caso da Alemanha revela uma versão da laicidade mais branda e menos impositiva de um modelo uniforme visionário de um único perfil de cidadão nacional. Vale dizer, o arcabouço jurídico de conformação do Estado não espera um processo de assimilação de diferentes culturas para a formação de um único 
povo. Até mesmo por questões históricas e o trauma gerado com os eventos discriminatórios perpetrados pelo Terceiro Reich, tem-se por evidente que a matriz jurídica forjou-se em sentido diametralmente oposto.

Dito isso, é um tanto quanto surpreendente que a Alemanha também esteja nesses últimos anos às voltas com a polêmica da restrição ao vestuário de natureza religiosa no caso de servidoras públicas, mais especificamente, de professoras muçulmanas adeptas do uso do véu. Quais seriam, portanto, os argumentos formulados nesse cenário? Haveria algum tipo de semelhança na realidade sociopolítica deste país e nos anteriormente analisados capaz de justificar a referida postura restritiva a tão importante direito fundamental?

Por ora, o que se pode afirmar é que a Alemanha tal qual a França vivenciou um mesmo fenômeno: a política estatal de imigração de trabalhadores, na sua maioria turcos, convocados para irrigar o mercado de trabalho no período crítico pós Segunda Guerra Mundial $^{75}$. Assim como na França, o período que se sucedeu à crise mundial da década de 70 não teve como consequência imediata o retorno de tais estrangeiros para seus países de origem. Políticas públicas de restrição migratória fomentaram, ao revés, a imigração de parentes e a instalação definitiva de diversas famílias adeptas do islamismo na Alemanha. Logo, aqui também os muçulmanos formam uma minoria religiosa com hábitos e práticas que destoam da acomodação paulatinamente construída por secularistas, protestantes e católicos $^{76}$. Senão, vejamos o histórico alemão.

A República Federal da Alemanha como o próprio nome indica é um Estado de matriz federal dividido cidades-territórios (Länder) e cidades-estados (Stadtstaaten) dotadas de competência legislativa e administrativa. Muito embora nos primeiros anos de formação pós Segunda Guerra, a prática indicasse o predomínio do federalismo de cooperação, mudanças político-partidárias, o processo de unificação da Alemanha em 1990 e o fortalecimento da União Europeia evidenciaram conflitos institucionais, a diversidade local e a força de demandas por maior autonomia. Em 2006, inicia-se, portanto, um processo de rearranjo do sistema federalista: por um lado a União pretendia diminuir os entraves do processo legislativo, que incluíam a oposição de vetos pelas unidades federadas e, por outro, estas desejavam ampliar a sua autonomia local. Com

75 FETZER, Joel S. e SOPER. J. Christopher. Op. Cit. (Ebook - posição 1.389 de 2.732).

${ }^{76}$ Atualmente, a população na Alemanha corresponde a 82 milhões de habitantes, dos quais 3,5 milhões filiam-se ao Islamismo. In HUMAN RIGHTS WATCH. Discrimination in the name of neutrality: headscarf bans for teachers and civil servants in Germany. Publicado em fevereiro de 2009. Disponível em: https://www.hrw.org/sites/default/files/reports/germany0209_webwcover.pdf, com acesso em 01/11/2014. 
efeito, as competências das unidades federadas em educação também foram ampliadas em âmbito local ${ }^{77}$.

Diante da extensa autonomia conferida às unidades federadas na Alemanha, a questão da indumentária religiosa das professoras muçulmanas nas escolas está, pois, sujeita a uma espécie de experimentalismo federativo variável de acordo com a compreensão de cada comunidade política quanto ao processo de integração e reconhecimento igualitário de minorias religiosas não integrantes da paleta cristã. Assim, diante da diversidade normativa estabelecida pelas unidades federativas quanto a esse tópico, a Alemanha encontra-se em uma situação sui generis: em algumas cidades, as professoras lecionam independentemente de seu credo religioso e do vestuário correlato ao passo que, em outras, tais mulheres são obrigadas a camuflar a sua identidade religiosa sob pena de banimento da instituição. Em Berlim, a norma possui um alcance ainda maior, com a vedação não só para professoras, mas também para diversos servidores públicos, como policiais, juízes, promotores de justiça, entre outros ${ }^{78}$.

Nessa esteira, os primeiros questionamentos quanto ao uso do véu remontam à década de 80 e dizem respeito ao sistema de identificação e de expedição de passaportes. Apesar de alguns casos terem chegado a cortes locais, no geral, foram aceitos sem que houvesse uma grande repercussão ou debate em âmbito nacional ${ }^{79}$.

O leading case da Alemanha é reconhecidamente o caso de Fereshta Ludin, afegã, muçulmana, naturalizada alemã e professora na região de Baden-Württemberg, que pretendia ocupar vaga de professora titular de uma escola local, tendo, por consequência, enfrentado forte resistência do Oberschulamt Stuttgartem (autoridade local máxima para a supervisão das escolas) em razão de sua opção pelo uso do hijāāb. Embora F. Ludin tenha obtido a graduação universitária para lecionar inglês, alemão e educação cívica para alunos do ensino básico (elementary and secondary school), a insistência no uso do véu fez com que esta fosse considerada inapta para ocupar um cargo como servidora pública.

Diante da recusa na sua contratação, F. Ludin ajuizou em 1998 ação perante a corte administrativa local, tendo recorrido sucessivamente para a Corte Administrativa Federal e para o Tribunal Constitucional Federal Alemão. Seu argumento era no sentido de que tais restrições seriam incompatíveis com o direito à liberdade de religião consagrado pela Constituição alemã.

77 V. LIMONGI, Dante Braz; P. D. PEREIRA, Diogo Modesto; BORGES, Diogo Njaine. Breve estudo sobre a estrutura constitucional alemã, o federalismo no país e sua última reforma. Direito, Sociedade e Estado. Jul/Dez 2011, n. 39, pp. 52/81.

$78 \mathrm{~V}$. HUMAN RIGHTS WATCH. Op. Cit.

79 Ibidem. p. 7. 
O Tribunal Constitucional Federal decidiu, a princípio, a favor de F. Ludin com fulcro na ideia de que restrições a direitos fundamentais deveriam ser delineadas em lei e que, no caso concreto, as decisões que a impediram de assumir o cargo de professora foram determinadas em sede administrativa sem correspondente norma legal. Em síntese, o Tribunal admitiu a possibilidade de restrição a tal direito bastando que atos normativos locais dispusessem de forma clara sobre o banimento de determinado vestuário.

A resposta política à decisão foi dada pelos parlamentos locais. Em pouco tempo, diversas unidades federativas, dentre elas a cidade de Baden-Württemberg, adequaramse à tese capitaneada pela Corte e editaram atos normativos com a finalidade de restringir o uso do véu nas escolas. Por certo, as leis e/ou emendas não chegaram a banir de forma literal o hijāb limitando-se a proibir o proselitismo religioso por parte dos professores de escolas públicas e/ou servidores públicos.

Relatório do grupo internacional de proteção aos direitos humanos Human Rights Watch, de fevereiro de 2009, voltado à análise desta temática no cenário alemão apresenta as seguintes considerações sobre a norma aprovada pelo parlamento da cidade de Baden-Württemberg:

Sob a égide da emenda do código escolar, os professores de escolas públicas não estão autorizados a 'fazer manifestações políticas, religiosas, ideológicas ou similares que possam ameaçar ou perturbar a neutralidade do país em relação aos alunos, aos pais ou à paz política, religiosa e ideológica da escola'. A lei coloca como 'particularmente ilegítimo' qualquer comportamento que possa parecer aos olhos dos alunos ou parentes uma demonstração do professor contra a dignidade humana, a igualdade de gênero de acordo com o Artigo 3 [da Lei Fundamental], os direitos à liberdade ou a livre e democrática ordem da Constituição. ${ }^{80}$

Sem dúvida, a opção pela vedação ao proselitismo religioso consistiu em um subterfúgio para a discriminação do uso do véu por professoras adeptas de uma minoria religiosa islâmica estranha ao status quo. A construção de barreiras sociais face ao crescimento do Islã e a incapacidade de compreender tal comunidade na condição de seres humanos merecedores de igual respeito e consideração, lógica própria à democracia

80 Ibidem. p. 26. 
e à proteção dos direitos fundamentais, evidenciou-se de forma irrefutável nas exceções estabelecidas pelo marco normativo local:

O trecho relevante do código escolar, todavia, diz que '[a] respectiva exibição de valores culturais ou tradições cristãs $e$ ocidentais não contradizem o 'dever de obediência' [do professor], e correspondem a objetivos educacionais. Ao promulgar tal lei, BadenWürttemberg buscava proibir professoras de escolas públicas de usarem o véu islâmico, enquanto permitia que as demais professoras continuassem a vestir indumentária e símbolos cristãos, tais como o hábito das freiras. ${ }^{81}$. (Grifou-se).

Outras unidades federativas acompanharam a tendência de excepcionar o vestuário culturalmente aceitável:

O regulamento da North Rhine-Westphalia adotou, em junho de 2006, reflete a linguagem da lei de Baden-Wurttemberg. A Bavária adotou tais restrições acerca dos véus, em 2004. "Hábitos de freiras são permitidos." No direito da Bavária, professores não são autorizados a usar roupas que são incompatíveis com os "valores fundamentais da Constituição e objetivos educacionais". No entanto, esses valores incluem valores culturais e educacionais cristão-ocidentais. As normas em vigor em Saarland, a partir de junho de 2004, enfatizam os valores e tradições cristãos: $A$ escola tem que ensinar e educar seus estudantes com base nos valores culturais $e$ educacionais cristãos, mostrando respeito pelos sentimentos de estudantes com diferentes visões. ${ }^{82}$

Quando o caso de F. Ludin retornou à análise das cortes administrativas locais, seu resultado acabou sendo o mesmo uma vez que Baden-Württemberg já havia aprovado emenda correspondente à proibição de manifestações religiosas e proselitistas nas escolas por parte dos professores. A justificativa dada pelos representantes do governo sobre a exceção criada para símbolos e vestimentas cristãos foi a de que tais valores já haviam

81 Locit.

Revista Publicum

Rio de Janeiro, v.2, n. 2, 2016, p. 254-323

http://www.e-publicacoes.uerj.br/index.php/publicum

DOI: 10.12957/publicum.2016.26368 
sido de tal forma assimilados pela sociedade, que haviam se descaracterizado como religiosos, tornando-se eminentemente culturais. Logo, manifestações de origem ocidental-cristã seriam neutras e incapazes de deturpar a ordem pública. A decisão final, portanto, seguiu esse mesmo caminho, reconhecendo um espaço diferenciado, porém, não discriminatório para a prática social cristã ${ }^{83}$.

Um segundo caso também levado às cortes locais de Baden-Württemberg foi o da professora da rede pública Doris Graber, que havia se convertido ao Islã. Professora há mais de 30 anos, ela começou a usar o véu em 1995, tendo lecionado tranquilamente por um período de 09 anos. Em 2004, foi ameaçada de perder o seu cargo caso não retirasse o véu. A Corte Administrativa de Stuttgart decidiu favoravelmente à requerente, sob o argumento de que dita proibição não poderia restringir-se à determinada minoria religiosa. Considerando-se que freiras continuariam a lecionar nas escolas com hábitos, esse seria uma espécie de tratamento desigual. Logo, não haveria porque discriminar as mulheres muçulmanas que tinham por prática religiosa o uso do véu. Nada obstante, tal decisão foi reformada em sede de recurso, e a justificativa para o tratamento diferenciado foi a partir da ideia de que o hábito das freiras consistia "um caso histórico especial, sob a égide um contrato básico único" ${ }^{84}$.

Diversos outros casos foram julgados pelas cortes locais seguindo esta mesma linha $\operatorname{argumentativa}^{85}$. A corte administrativa de Düsseldorf chegou a proibir uma professora de usar um chapéu tipo baret cor de rosa, que cobria toda a sua cabeça e orelha, por se tratar de uma espécie de fraude à lei. A única opção seria o uso de perucas, o que foi rechaçado pela professora (julgamento da Corte Trabalhista Estadual, em 10/04/2008, Ref. 5 Sa 1836/07). ${ }^{86}$.

A diferença no tratamento entre as unidades federadas e a constante litigâncias das mulheres muçulmanas em busca de aceitação têm mantido o tema em destaque. Por

83 FOGEL, Ruben Seth. Headscarves in german public schools: religious minorities are welcome in German, unless - God forbid - they are religious. New York Law School Law Review. Vol. 51, 2006/2007. pp. 619-653.

${ }^{84}$ HUMAN RIGHTS WATCH. Op. Cit. pp. 32-33.

85 "Argumentos similares aos utilizados em julgamentos da Corte Administrativa de Düsseldorf podem, também, ser encontrados em decisões proferidas em outros casos por cortes administrativas ou trabalhistas do estado (por exemplo, a Corte Administrativa de Aachen, em novembro de 2007; Corte Administrativa de Gelsenkirchen, em fevereiro de 2008; Corte Trabalhista de Düsseldorf, em junho de 2007; [120] Corte Trabalhista de Hern, em março de 2007 (e Corte Trabalhista do Estado, em outubro de 2008). [121]. Além disso, em julho de 2008, a Corte Trabalhista de Wuppertal rejeitou o caso de uma professora muçulmana, empregada desde 2002 e que havia sido demitida ao se recusar a retirar o véu durante as aulas (após ter recebido um aviso prévio). Discriminação em nome da neutralidade: o banimento de véus para professores e funcionários públicos na Alemanha". Ibidem. p. 34.

${ }^{86}$ Locit.

Revista Publicum

Rio de Janeiro, v.2, n. 2, 2016, p. 254-323

http://www.e-publicacoes.uerj.br/index.php/publicum

DOI: 10.12957/publicum.2016.26368 
certo, as leis locais restritivas e as correspondentes decisões judiciais que ratificaram a validade desses atos normativos não tiveram o condão de sedimentar o assunto no seio social.

Em 27 de janeiro de 2015, o Tribunal Constitucional Federal decidiu sobre outros dois casos envolvendo o uso do véu (1 BvR 471/10 e 1 BvR 1181/10) ${ }^{87}$. Desta vez, contudo, a corte deparou-se com uma intensa mobilização da sociedade civil e, sobretudo, de organizações protetivas de direitos humanos, tais como a Human Rights Watch e a Open Society Foundations, que nessa esteira voltaram suas energias para a reforma do paradigma de F. Lundin. Tais entidades elaboraram relatórios, como o citado neste trabalho, e estudos entregues à Corte por meio do Programa Justice Initiative ${ }^{88}$.

Por óbvio, o julgamento de tais decisões correspondeu a uma etapa essencial do diálogo institucional/social sobre o caso na Alemanha, em um momento em que o debate sobre tais restrições encontrava-se mais amadurecido, com a participação de atores engajados na defesa de direitos humanos e a avaliação dos efeitos de tal escolha sobre a liberdade de religião, a autonomia das mulheres e a conformação de um estado democrático plural ${ }^{89}$.

Com efeito, o Tribunal Constitucional Federal alemão entendeu que a restrição ao uso do véu ou outras vestimentas de caráter religioso às professoras e profissionais da educação seria inconstitucional, salvo em casos excepcionais de perigo amplo e concreto, o que por certo não era o caso da requerente. Em suma, a Corte alemã reconheceu o direito ao uso do véu como uma projeção do direito à privacidade, à intimidade e à liberdade religiosa. Nessa esteira, entendeu que tampouco seria possível criar uma restrição a um determinado grupo religioso e afastá-la para os demais, evidenciando-se

${ }^{87}$ Tribunal Constitucional Federal da Alemanha, casos (i) 1 BvR 471/10; e (ii) 1 BvR 1181/10. Decisão disponível

em: https://www.bundesverfassungsgericht.de/SharedDocs/Entscheidungen/DE/2015/01/rs20150127_ 1bvr047110.html, com acesso em 12/11/2016.

${ }^{88} \mathrm{~A}$ Open Society elaborou uma espécie de estudo/memorial para o Tribunal Constitucional Federal da Alemanha, com o título "Observations in the cases 1 BvR 471/10 e 1 BvR 1181/10, before de the Federal Constitutional Court of Germany", correspondente a um estudo legal sobre diretivas da União Europeia, protetivas da igualdade de gênero, da igualdade racial, e sobre a Convenção Europeia de Direitos Humanos, aplicáveis em face da proibição do uso de véu por professoras". Disponível em: http://www.opensocietyfoundations.org/sites/default/files/domestic-headscarvesobservations-eng-20120305.pdf. Acesso em 11/11/2014.

${ }^{89}$ Notícias sobre a decisão da corte alemã: (i) German court rules against banning veil in schools, but Europe remains divided. The conversation, em 23/03/15, Disponível em: $<$ https://theconversation.com/german-court-rules-against-banning-veil-in-schools-but-europeremains-divided-39077>; (ii) Germany courts ends ban on Islamic headscarves for teachers, $B B C$ News, em 13/03/2015. Disponível em http://www.bbc.com/news/world-europe-31867732, com acesso em 12/11/2016. 
assim uma preferência injustificável. Além disso, não haveria nada no uso do véu por si só que pudesse causar prejuízo ao ambiente e ao processo educacional.

Como era de se esperar, diante do contexto político e social delineado supra e que se mescla a problemas como (i) uma nova onda mundial refratária ao fenômeno da globalização; e (ii) a intensificação de ataques terroristas promovidos por grupos islâmicos na Europa, sobretudo, em França; a decisão do Tribunal Constitucional alemão não teve o condão de encerrar o debate sobre o uso do véu e correlatos.

Em 14 de abril de 2016, o Juiz Andreas Ditter, da capital (Berlim) rejeitou o pedido de uma professora para usar o véu na sala de aula. Afirmou que muito embora a requerente tivesse direito à liberdade de religião, esta haveria de se curvar à lei de neutralidade a qual preconiza que em determinadas situações servidores públicos civis não poderiam expor suas visões religiosas e ideológicas por meio do seu vestuário ${ }^{90}$.

Nessa toada, em 18 de agosto de 2016, em uma conferência de imprensa, o Ministro do Interior alemão, ao debater novas medidas de segurança, deu a entender que uma regulação de restrição ao uso de véus islâmicos completos (como o niqab e a burqa, por exemplo) estaria sendo elaborada pelo governo alemão. O Ministro disse à imprensa que: "Isso não é compatível com a nossa sociedade aberta. Mostrar o rosto é crucial para a comunicação, para a vida conjunta e para a união em nossa sociedade". Nessa esteira, completou: "Nas áreas em que a visibilidade do rosto de um indivíduo tem uma função, nós queremos tornar isso uma regra... e isso significa que, qualquer um que venha quebrar a regra deverá sofrer as consequências" $"$.

Tais declarações foram destaque na matéria intitulada "A possível restrição à burca na Alemanha tem um problema: onde estão as burcas?"92 Neste artigo, o autor chama a atenção para o fato curioso de que haveria pouquíssimas mulheres usando tais vestimentas na Alemanha. Chegou-se à conclusão após pesquisa junto aos experts e instituições que lidam com esse tema que haveria algo em torno de 300 mulheres usando o niqab em todo o país. Por outro lado, nenhuma mulher teria até este momento sido vista na Alemanha usando uma burca. Diante desses fatos, o jornalista alemão Fabian Köler lançou um desafio nas redes sociais a fim de descobrir se alguém afinal usaria burca

90 Muslim teacher banned from wearing veil in class after court battle. Sunday Express, em 15/04/16. Disponível em: http://www.express.co.uk/news/world/661368/Muslim-teacher-womanbanned-wearing-veil-burka-class-court-Germany, com acesso em 12/11/2016.

${ }^{1}$ TAYLOR, A. Germany's potential burqa ban has a problem: Where are the burqas? The Washigton Post, em 19/08/2016. Disponivel em: https://www.washingtonpost.com/news/worldviews/wp/2016/08/19/germanys-potential-burqaban-has-a-problem-where-are-the-burqas/, com acesso em 12/11/2016. Disponível também em: <http://edition.cnn.com/2016/08/19/europe/germany-veil-ban/>, com acesso em 12/11/2016.

92 Ibidem. 
na Alemanha, tendo feito o seguinte pedido: -"Se você tiver visto uma burca na Alemanha, me avise". Apesar de algumas situações inusitadas, ninguém viu uma mulher de burca neste país.

Logo, a crítica forjada a esse movimento não poderia ser outra: ao que tudo indica existem mais pessoas contrárias ao uso da burca na Alemanha que pessoas efetivamente as usando como vestimenta nas ruas. $\mathrm{O}$ autor menciona que em um país com mais de 4.7 milhões de habitantes, as mulheres que de fato usam o niqab e a burca representam algo em torno de 0,01\% da população. E completa: “Pode parecer estranho que se queira implementar o banimento de uma peça de roupa ao mesmo tempo em que se tem pouca informação sobre quem de fato a veste; assim como se está diante de uma grande confusão pública sobre o que essas peças de roupa realmente são"93.

Mais recentemente, na segunda metade do presente ano, a polêmica do uso do véu chegou ao Poder Judiciário por outras vias. Associações de magistrados alemãs estão na linha de frente política pleiteando o banimento do uso do véu por juízas e advogadas, novamente sob o argumento da promoção da neutralidade ${ }^{94}$.

Este é o cenário, pois, na Alemanha.

\section{Análise Comparativa}

Os três países ${ }^{95}$ analisados neste estudo podem ser descritos como Estados Democráticos de Direito adeptos do constitucionalismo moderno ${ }^{96}$. Elaboraram cartas constitucionais como documentos-guia da atuação estatal com força normativa e superioridade perante o conjunto do ordenamento jurídico. Além disso, instituíram, ainda que em formatos diferentes, órgãos com perfil judicial, responsáveis pelo controle de constitucionalidade de atos normativos e/ou com competência para apreciação de decisões dos órgãos da Administração Pública, tendo como parâmetro normas constitucionais.

\footnotetext{
93 Ibidem.

${ }^{94}$ German judges call for headscarf ban in court to show 'neutrality'. Independent, em 09/08/2016. Informação disponível em <http://www.independent.co.uk/news/world/europe/german-judgescall-for-headscarf-hijab-ban-in-court-lawyers-to-show-neutrality-a7180591.html>, com acesso em $13 / 11 / 2016$.

${ }_{95}$ Ver considerações gerais sobre o momento histórico vivenciado pela Turquia na nota de roadapé n. 01.

96 "O constitucionalismo moderno se assenta em três pilares: a contenção do poder dos governantes, por meio da separação de poderes; a garantia de direitos individuais, concebidos como direitos negativos oponíveis ao Estado; e a necessidade de legitimação do governo pelo consentimento dos governados, pela via da democracia representativa". SARMENTO, Daniel; e Souza Neto, Cláudio Pereira de Souza. Direito constitucional: teoria, história e métodos de trabalho. Belo Horizonte: Fórum, 2013. P. 72.
} 
Nessa esteira, os três países consagraram em suas respectivas constituições diversos direitos fundamentais, dentre eles a liberdade de religião. Assim sendo, pautamse cada qual pelos seguintes mandamentos constitucionais:

TURQUIA: Constituição de 18/10/1982: ARTIGO 2‥ A República da Turquia é um Estado democrático, secular e social regido pelo Estado de Direito, inserido das noções de paz pública, solidariedade nacional e justiça, respeito aos direitos humanos, leal ao nacionalismo de Atatürk e baseado nos princípios fundamentais estabelecidos no preâmbulo. (...) ARTIGO 10 - Todos são iguais perante a lei, sem distinção de língua, raça, cor, sexo, opinião política, crença filosófica, religião e seita, ou quaisquer outros fundamentos. (...) Artigo 24 Todos têm a liberdade de consciência, crença religiosa e conviç̧ão (...) Ninguém será obrigado a adorar, a participar de cerimônias ou ritos religiosos, a revelar crenças religiosas e convicções, ou ser culpado ou acusado por causa de suas crenças religiosas $e$ convicções. (Grifou-se).

FRANÇA - (i) Constituição de 03/06/1958: “Art. 1‥ A França é uma República indivisível, laica, democrática e social. Assegura a igualdade de todos os cidadãos perante a lei sem distinção de origem, raça ou religião. Respeita todas as crenças. Sua organização é descentralizada. A lei promove a igualdade de acesso das mulheres e dos homens aos mandatos eleitorais e funções eletivas, bem como às responsabilidades profissionais e sociais"; (ii) Preâmbulo da Constituição de 27/10/1946: "1. No dia seguinte à vitória conquistada pelos povos livres sobre os regimes que tentaram dominar e degradar a pessoa humana, o povo francês proclama novamente que qualquer ser humano, sem distinção de raça, de religião nem de crença, possui direitos inalienáveis e consagrados"; (iii) Declaração de Direitos do Homem e do Cidadão de 1789: (...) IV A liberdade consiste em poder fazer tudo o que não prejudica outrem: assim, o exercício dos direitos naturais de cada homem tem limites apenas no que assegura aos outros membros da sociedade o gozo desses mesmos direitos. Esses limites somente podem ser 
determinados pela Lei. (...) X - Ninguém pode ser assediado por causa de suas opiniões, mesmo religiosas, desde que sua manifestação não perturbe a ordem pública estabelecida pela lei. (...) XVI - Qualquer sociedade na qual a garantia dos direitos não está assegurada, nem a separação dos poderes determinada, não tem Constituição alguma". (Grifou-se).

ALEMANHA: Lei Fundamental de 1949: Artigo 1. (1) A dignidade da pessoa humana é intangível. Respeitá-la e protegê-la é obrigação de todo o poder público. (2) o povo alemão reconhece, por isto, os direitos invioláveis e inalienáveis da pessoa humana como fundamento de toda comunidade humana, da paz e da justiça do mundo. (3) Os direitos fundamentais, discriminados a seguir, constituem direitos diretamente aplicáveis e vinculam os poderes legislativo, executivo e judiciário. Artigo 2. (1) Todos têm direito ao livre desenvolvimento de sua personalidade, desde que não violem os direitos de outros e não atentem contra a ordem constitucional ou a lei moral. (...) Artigo 3. (...) (3) Ninguém poderá ser prejudicado ou favorecido por causa de seu sexo, da sua descendência, da sua raça, do seu idioma, de sua pátria de origem, da sua crença, ou das suas conviç̧ões religiosas ou políticas. (...) Artigo 4. (1) A liberdade de crença, de consciência, e a liberdade de confissão religiosa e ideológica são invioláveis. (2) É assegurado o livre exercício da religião. (...) Artigo 19 (1) Na medida em que, segundo esta Lei Fundamental, um direito fundamental possa ser restringido por lei ou em virtude de lei, essa lei tem que ser genérica e não limitada a um caso particular. Além disso, a lei terá de citar o direito fundamental em questão, indicando o artigo correspondente. (2) Em nenhum caso um direito fundamental pode ser violado em sua essência. (...) Artigo 33. (...) (2) Todos os alemães têm igual acesso a qualquer cargo público, de acordo com a sua aptidão, capacidade e desempenho profissional. (3) 0 gozo dos direitos civis e cívicos, a admissão a cargos públicos, bem como os direitos adquiridos no serviço público são independentes da confissão religiosa. Ninguém

Revista Publicum

Rio de Janeiro, v.2, n. 2, 2016, p. 254-323

http://www.e-publicacoes.uerj.br/index.php/publicum

DOI: $10.12957 /$ publicum.2016.26368 
poderá sofrer discriminação por professar ou deixar de professar determinada religião ou ideologia. (Grifou-se).

Não se deve olvidar que esses Estados também aderiram ao Conselho da Europa e ratificaram a Convenção Europeia de Direitos do Homem, a qual também alberga a liberdade de religião como um direito fundamental.

Convenção para a proteção dos direitos do homem e das liberdades fundamentais (Roma, 04/11/1950): (...) Artigo 9. 1. Qualquer pessoa tem direito à liberdade de pensamento, de consciência e de religião; este direito implica a liberdade de mudar de religião ou de crença, assim como a liberdade de manifestar a sua religião ou a sua crença, individual ou colectivamente, em público e em privado, por meio do culto, do ensino, de práticas e da celebração de ritos. 2. A liberdade de manifestar a sua religião ou convicções, individual ou colectivamente, não pode ser objecto de outras restrições senão as que, previstas na lei, constituírem disposições necessárias, numa sociedade democrática, à segurança pública, à protecção da ordem, da saúde e moral públicas, ou à protecção dos direitos e liberdades de outrem". (Grifou-se).

O que se nota, portanto, é que cada qual com a sua linguagem, de forma mais ou menos incisiva, todos os países analisados reconhecem a posição privilegiada aos direitos fundamentais e dentre eles o livre exercício da liberdade religiosa, bem como a vedação a qualquer tratamento discriminatório correlato.

Logo, o ponto controverso desse debate consiste em saber se o uso de símbolos e vestimentas religiosas integra o direito fundamental à liberdade de religião e nessa condição é passível de restrições legais ou administrativas. Vale dizer: os Estados podem restringir essa prática com fundamento na ordem pública, na preservação de direitos das mulheres, ou no laicismo forte e, consequentemente, na vedação ao proselitismo?

Como delineado supra, este estudo defende que tais restrições apenas poderiam ser admitidas em casos excepcionalíssimos, em que restasse caracterizada uma questão evidente e concreta de perigo à ordem pública, o que não se verificou em nenhum dos 
casos analisados nos itens anteriores ${ }^{97}$. Isso porque a cláusula geral de liberdade protege a escolha da vestimenta do cidadão, sob dois aspectos.

A uma, a escolha das roupas e acessórios por si só são reflexo da individualidade e do projeto de vida assumido por cada pessoa. O Estado não tem poder para adentrar na esfera privada e emocional do indivíduo de modo a determinar qual roupa melhor se adéqua ao seu perfil. Trata-se de uma escolha íntima e motivada por aspectos existenciais e psicológicos: vestir-se é escolher quem se é quem se deseja ser e o Estado simplesmente não tem legitimidade para interferir nesse aspecto da vida humana.

A duas, a vestimenta de natureza religiosa além de estar respaldada no direito à autonomia e livre desenvolvimento da personalidade está ainda resguardada como prática religiosa. Pretender enquadrar a vestimenta como um excesso do exercício da liberdade de religião consiste no mesmo em querer definir os limites aceitáveis do exercício da religião alheia. Não cabe ao Estado nem às outras denominações religiosas aferir se as práticas de uma determinada religião são racionais ou consentâneas à moral comum. A liberdade de religião, ao revés, consiste em aceitar todo e qualquer ato racional ou irracional manifestado em razão de uma crença pessoal. É o direito que o ser humano tem de acreditar no que ele quiser, da forma que ele quiser, manifestando-se como bem entender. Restrições a esse direito merecem argumentos sólidos e fundamentados em perigos concretos, forjados a partir de um raciocínio coerente.

Os principais argumentos ventilados nos três países são: (i) a predominância de um Estado secular fundado no laicismo forte; (ii) dever de proteção das mulheres contra práticas religiosas opressivas; (iii) proteção de estudantes e da comunidade contra agentes proselitistas de credos religiosos não integrados ao status quo, na condição de professores.

A versão forte da laicidade, argumento central dos opositores do uso véu pelas mulheres muçulmanas em espaços públicos, forja-se na ideia de que o Estado não apenas é laico como ele deve promover valores seculares na sociedade. A escola seria o espaço central por natureza dessa política e, portanto, não poderia aceitar qualquer tipo de manifestação religiosa capaz de perturbar essa missão do Estado. Tampouco os órgãos

${ }^{97}$ Seria possível afirmar que a prática de rituais de sepultamento tradicionais em comunidades de Serra Leoa, Nigéria, Senegal, Guiné e Libéria, atingidos recentemente por uma epidemia de ebola seriam passíveis de restrições, ante o evidente perigo à ordem pública, consistente na disseminação do vírus, cujo impacto na região tem sido devastador. Tal restrição ao direito fundamental poderia ser justificada ante um caso concreto de perigo a toda a população. Também poderíamos identificar o exemplo do presidiário Sikh, que pretende portar consigo a tradicional adaga, símbolo de natureza religiosa. Considerando-se que os presídios necessitam de regras de segurança, e que a adaga poderia ser utilizada servir de arma, tem-se por justificável a restrição nessa hipótese à liberdade de religião. 
públicos, serviços públicos e repartições poderiam ter em seus quadros indivíduos que revelassem as suas preferências religiosas. Tais manifestações estariam em contrariedade à ideia de neutralidade própria ao Estado laico.

Tal concepção do laicismo revela-se extremamente poderosa na Turquia e na França como visto linhas acima. Trata-se, inclusive, de uma linha ideológica defendida por parte dos professores franceses que em diversas oportunidades chegaram a entrar em greve contra a presença de alunas muçulmanas adeptas do uso do véu. É a percepção de que a religião é uma espécie de "mal tolerável" restrita à vida privada e incoerente com o espaço público. O uso de determinado vestuário religioso é encarado como um privilégio desigual. Todos devem seguir um modelo definido pelo Estado pautado pelo republicanismo cívico. O bom cidadão é aquele que se subsome à vontade geral e aceita os valores comuns da sociedade.

A nosso ver, em sintonia com as reflexões propostas por Habermas, a concepção de laicismo forte não se adéqua ao espírito dos Estados democráticos de direito que têm como premissa fundamental a proteção de direitos individuais. Tal entendimento revela a pretensão de reduzir a liberdade de religião àquilo que o Estado pretende que ela seja. Trata-se, portanto, de uma contradição. O Estado deve promover valores neutros, mas na verdade ele promove valores seculares que por si só não são neutros. O não reconhecimento do fenômeno religioso também revela uma concepção ideológica. Existe, a bem da verdade, uma confusão entre laicismo e secularismo. Enquanto o primeiro sustenta-se na separação entre o Estado e qualquer grupo religioso, o segundo propõe a consagração de valores existenciais racionais. O Estado democrático de direito laico deve, por um lado, garantir essa separação entre Estado e religião e, por outro, promover a convivência pacífica entre as diversas crenças e ideologias sem pinçar uma como a mais adequada.

O secularismo assertivo, portanto, ao fortalecer o caráter laico do Estado esvazia o conteúdo essencial do direito à liberdade religiosa. Essa formatação impositiva revela-se tão autoritária quanto àquelas defendidas por fundamentalistas religiosos que buscam moldar toda a sociedade a uma única visão de mundo: preferencialmente àquela defendida pelo agente. Para Habermas:

A compreensão perspicaz de cidadãos seculares, de que é preciso viver numa sociedade pós-secular sintonizada epistemicamente com a sobrevivência de comunidades religiosas, depende de uma mudança de mentalidade cujas pretensões não são menores do que 
as de uma consciência religiosa que precisa adaptar-se aos desafios do entorno que se seculariza cada vez mais (...) Pressupõe-se um enfoque epistêmico que resulta da certificação autocrítica dos limites da razão secular. Tal pressuposição significa que o etos democrático de cidadãos do Estado (na interpretação por mim sugerida) só pode ser imputado simetricamente a todos os cidadãos se estes, tanto os seculares como os religiosos, passarem por processos de aprendizagem complementares. ${ }^{98}$

A nova configuração da sociedade marcada pela crescente confluência social do Oriente com o Ocidente demandará a devida acomodação dos secularistas a uma proposta de laicismo fraco capaz de manter a estrutura de separação entre Estado e religião, porém, aberta à proteção de direitos fundamentais como a liberdade religiosa. Do contrário, tal qual a Igreja Católica no passado, os secularistas do presente pretenderão não a neutralidade, mas a imposição da formação de um ser humano monolítico racional criado à luz de um modelo único de cidadania. A crença na formatação do cidadão secular por meio de um processo educacional, forjado a partir da revelação da razão com a consequente abdicação de crenças religiosas, traduz não só uma postura autoritária perante a formação da identidade individual, mas também uma visão reduzida sobre a natureza humana.

Outro argumento central das proibições à liberdade ao vestuário religioso volta-se para a proteção de direitos das mulheres contra a opressão religiosa. Parte dos defensores da proibição do uso do véu acredita que tais medidas fortalecerão as mulheres a se oporem a esse tipo de "dominação" e se tornarem pessoas livres. Acreditam também que tal medida protege aquelas alunas que não desejam usar o véu e sentem-se oprimidas pelas colegas praticantes.

Tal defesa, contudo, possui diversos percalços.

A problemática da opressão feminina não foi, não é e nunca será um tema restrito à religião muçulmana. Países reconhecidos pela vanguarda no processo democrático e de consagração de direitos fundamentais possuem sólidos grupos feministas que dia a dia denunciam práticas sexistas nas relações de trabalho, familiares e comunitárias. A questão do encapsulamento das mulheres ao ambiente privado gerou há aproximadamente 50 anos uma revolução no seio da sociedade americana. Em 1963, Betty Friedman publicou a obra "A mística feminina", pela qual apresentava a sua versão "do problema sem nome":

98 HABERMAS, Jürgen. Op. Cit. p. 158.

Revista Publicum

Rio de Janeiro, v.2, n. 2, 2016, p. 254-323

http://www.e-publicacoes.uerj.br/index.php/publicum

DOI: $10.12957 /$ publicum.2016.26368 
mulheres que na metade do século $X X$ que se dedicavam às suas tarefas domésticas e à sua família e se perguntavam "é só isso" ${ }^{99}$ ? O discurso velado sobre a incapacidade de profissionalização das mulheres, o sistema de divisão de tarefas e a consagração da mulher como heroína do lar foram e ainda são questões no mundo ocidental. Por acaso, o não reconhecimento das mulheres para a prática do sacerdócio na religião cristã motiva tamanha mobilização? Não seria o caso de obrigar também às freiras a despirem-se de seus hábitos de modo a promover a igualdade de gênero na Igreja Católica?

Afirmar de modo abstrato que crianças, adolescentes e mulheres muçulmanas são oprimidas pelo uso do véu corresponde à reprodução de uma concepção simplista do Islã. As meninas muçulmanas que frequentam escolas não estão alijadas do convívio social plural, ao revés, integram famílias que veem na educação escolar um caminho de crescimento pessoal. Do contrário, iniciariam suas filhas em processos de educação domiciliar ou familiar. O regime patriarcal que existe no Ocidente e no Oriente se manifesta por diversas formas adentrando na vida cotidiana por meio de processos culturais e sociais imbricados e complexos.

Se um dos objetivos do Estado é estender as mãos para essas meninas para que elas possam encontrar caminhos de construção de uma autonomia pessoal, entendo que o foco não deve ser o uso ou não do véu, mas sim o amplo acesso ao espaço público, sobretudo, ao universo escolar. Todos os caminhos devem ser construídos para que todas as mulheres tenham alternativas. Cada uma delas terá o espaço para construir a autonomia que for possível e que parta de um sentimento genuíno, capaz de desenhar um plano de vida único. Algumas seguirão com o véu, outras não. Por certo, não se está diante de uma questão fácil. A pauta de gênero é marcada por demandas que aparentemente são contraditórias, tais como proteção e autonomia. O grande desafio consiste em entender os limites recíprocos desse arranjo, sobretudo, quando conjugados com a temática de religiões à margem do status quo.

A meu ver, as lições de Nancy Fraser nos auxiliam a percorrer esse caminho. A uma, porque sua narrativa universal evidencia um dado da realidade: a questão de gênero não é um problema particular da comunidade muçulmana. Os argumentos alinhavados pela autora sobre a problemática de gênero são construídos de forma abrangente:

Da perspectiva da ordem do status, entretanto, o gênero abrange elementos que são mais próximos da sexualidade do que da classe $e$

99 FRIEDAN, Betty. The feminine mystique. New York: W.W. Norton \& Company. 2007.

Revista Publicum

Rio de Janeiro, v.2, n. 2, 2016, p. 254-323

http://www.e-publicacoes.uerj.br/index.php/publicum

DOI: $10.12957 /$ publicum.2016.26368 
que o lançam diretamente na problemática do reconhecimento. 0 gênero codifica padrões difundidos de valor cultural, que são centrais para a ordem do status como um todo. Como resultado, não apenas as mulheres, mas todos os grupos de baixo status, correm o risco de ser feminilizados (feminized) e, consequentemente, diminuídos. Assim, uma das principais características da injustiça de gênero é o androcentrismo: um padrão de valor cultural institucionalizado que privilegia traços associados à masculinidade, enquanto deprecia tudo o que codifica como 'feminino'. O resultado é interpretar mulheres e meninas como outras subordinadas e deficientes que não podem participar como iguais na vida social. Difusamente institucionalizado, esse padrão valorativo androcêntrico gera formas de subordinação de status específicas de gênero, incluindo violência sexual, violência doméstica, tutela por toda a vida, casamentos arranjados, morte por dote, estupros em massa como arma de guerra, mutilação genital e escravização sexual. E ainda, a negação da integridade corporal, da liberdade reprodutiva, e da autodeterminação sexual. Além disso, reduzido acesso à moradia, à alimentação, à terra, à saúde e à educação; prejuízos em seus direitos de imigração, naturalização e asilo; exclusão e marginalização da sociedade civil e da vida política, estereotipagem (stereotyping) e objetificação (objetification); $e$ perseguição e depreciação na vida cotidiana. Esses danos são injustiças de reconhecimento ${ }^{100}$.

A duas, porque ela abre as portas para a construção de uma ideia de justiça que abraça, ao mesmo tempo, políticas de redistribuição e reconhecimento. Nessa esteira, a autora propõe a reavaliação de identidades desrespeitadas e a valorização positiva da diversidade cultural ${ }^{101}$. Sob essa ótica, a ideia de reconhecimento impõe uma reconstrução do sentido não só do outro, mas também da nossa própria cultura. $O$ caminho de compreensão da diferença passa por um processo inicial de autoanálise.

E cabe aqui propormos a seguinte indagação: tais mulheres, as que usam o véu, são as mais oprimidas da sociedade francesa? Será que as modelos, muitas adolescentes de 12 a 17 anos, que desfilam nas passarelas na semana de moda em Paris e se submetem a

100 FRASER, Nancy. Op. Cit. pp. 174-175.

101 Ibidem. p. 170.

Revista Publicum

Rio de Janeiro, v.2, n. 2, 2016, p. 254-323

http://www.e-publicacoes.uerj.br/index.php/publicum

DOI: $10.12957 /$ publicum.2016.26368 
regimes forçados, desenvolvendo anorexia e bulimia, para adequar-se aos padrões estéticos de beleza na magreza extrema, estão em um grau de opressão inferior ou superior às adolescentes que usam o hijāb? O debate sobre o véu não é sobre gênero. Nunca foi. Trata-se de pinçar argumentos para o disfarce daquilo que não se pode dizer. $E$ por dever de coerência e lealdade, não acredito que o feminismo deva ser utilizado para fins escusos. Porque se nós formos falar mesmo sobre direitos das mulheres, nós devemos começar pelos filósofos franceses e iluministas e sobre a pretensa igualdade de uma Revolução Francesa que nasceu e se consolidou patriarcal. Os franceses estão dispostos a deparar-se com os seus próprios fantasmas ${ }^{102}$ ?

Por que o Estado deve dizer como as mulheres devem percorrer a sua trajetória de vida, adentrando em seus armários para que obrigatoriamente sigam um caminho iluminado escolhido por terceiros? Trata-se de uma restrição à liberdade de religião que decorre de uma fórmula paternalista e de certa forma reproduz a problemática de gênero ocidental: a identificação da mulher como um sujeito oprimido e frágil. O Estado, representante da vontade geral da sociedade, acredita-se apto a dizer ao indivíduo e, sobretudo, às mulheres, que tipo de atitudes eles deveriam tomar, pois parte do pressuposto que eles e elas não seriam capazes de promover medidas protetivas por si só. Nessa esteira, pouco importa se a escolha do uso do véu decorre da sua vontade ou de uma imposição externa, o Estado é que deve saber o que é melhor para seus governados.

102 Lynn Hunt apresenta evidências contundentes sobre o maior e mais importante paradoxo da Revolução Francesa: se por um lado os revolucionários pretendiam a total separação da vida pública da vida privada, por outro, defendiam a exclusão das mulheres da arena política, com base nas lições do poder patriarcal familiar. A razão pela qual basicamente as mulheres não podem participar da política é que elas são mães, irmãs, filhas e esposas, personagens com um papel definido na arena associativa familiar. Essas mulheres não poderiam abrir mão ou deixar de lado suas responsabilidades em prol da discussão pública. As demais mulheres - da vida - tampouco tinham o que acrescentar ao universo político. Vejamos o seguinte trecho do artigo Revolução Francesa e Vida Privada: "Aos olhos dos deputados, nesse auge de radicalidade revolucionária - o momento da descristianização -, a politização da indumentária ameaçava subverter a própria definição da ordem dos sexos. O Comitê de Segurança Geral temia que os debates sobre o vestuário fossem resultantes da masculinização das mulheres: 'Hoje se exige o barrete vermelho: não vão parar por aí; logo exigirão o cinto com pistolas'. Mulheres armadas na longa fila do pão seriam bem mais perigosas; e o pior era que fundavam associações. Fabre d'Églantine observou que 'essas sociedades não são absolutamente compostas de mães de família, de moças de família, de irmãs que cuidam de seus irmãozinhos menores, e sim de uma espécie de aventureiras, de cavaleiras andantes, de jovens emancipadas, de mocetonas de modos livres e soltos. Os aplausos que o interromperam mostram que ele havia tocado na corda sensível dos deputados; todas as associações femininas foram suprimidas, pois iam contra a 'ordem natural', na medida em que 'emancipavam' as mulheres de sua identidade exclusivamente familiar (privada)". HUNT, Lynn. Revolução francesa e vida privada. In ARIÈS, Philippe e DUBY, Georges (org.) História da vida privada: da renascença ao século das luzes. São Paulo: Companhia das Letras, 2009. p. 22.

Revista Publicum

Rio de Janeiro, v.2, n. 2, 2016, p. 254-323

http://www.e-publicacoes.uerj.br/index.php/publicum

DOI: 10.12957/publicum.2016.26368 
Estamos aqui diante de medidas que visam à promoção da liberdade do indivíduo por meio de restrições à sua autonomia ${ }^{103}$.

Evidentemente que tal fórmula não se adéqua à estrutura de proteção de autonomia e liberdade propostas pelas respectivas constituições e pela Convenção Europeia de Direitos Humanos. A autodeterminação para a escolha da prática religiosa - e, consequentemente, do vestuário correspondente - não estão passíveis de arbitramento pelo Estado, seja em nome de um republicanismo cívico, seja em nome de uma suposta política de gênero.

O efeito perverso desses supostos atos de libertação não é outro senão o alijamento das crianças e, sobretudo, das meninas do ambiente escolar. Na França, a restrição do uso de vestimentas religiosas acabou atingindo também diversos alunos da religião Sikh adeptos do uso do turbante. O processo de n. 285396 (ECLI:FR:CESSR:2007:285396.20071205) julgado pelo Conselho de Estado francês, em 05/12/2007, confirmou a exclusão do aluno M. A. do Liceu Louise Michel de Bobiny, ante a ostensividade deste acessório. Assim, para promover a liberdade de alguns alunos e alunas, outros terão que se privar do convívio educacional e multifacetado, restringindose à educação doméstica ou quando não for o caso de total desmotivação com o abandono dos estudos. É difícil compreender como o uso de um acessório de vestimenta pode ser pior que banir crianças da comunidade educacional e como tal medida seria capaz de fortalecer a igualdade de gênero.

Por fim, a ostensividade dos símbolos e vestimentas religiosos como fator de proselitismo religioso é o terceiro argumento utilizado pelos países analisados. No caso da França, passou a integrar a redação do Código de Educação e, no caso da Alemanha, tem sido utilizado como fórmula de discriminação entre religiões estranhas à acomodação secular/cristã vistas como "exuberantes" em relação ao modelo ocidental.

Tal percepção da religião muçulmana indica uma reprodução do velho preconceito colonialista, o qual recepciona outras culturas exaltando a sua excentricidade ao mesmo tempo em que alimenta em seu ego a ideia de que não suficientemente desenvolvidas e civilizadas como a sua ${ }^{104}$. A alegação do poder legislativo e das cortes locais alemães de que o uso de símbolos e vestimentas por minorias religiosas seria ofensivo ao padrão cultural, com ressalvas para as práticas cristãs, choca-se frontalmente com os valores

103 BERLIN, Isaiah. Two concepts of liberty. In The Proper study of mankind: an anthology of essays. London: Pimlico (EBOOK). 1998.

104 V. BORTOLUCI, José Henrique. Pensamento eurocêntrico, modernidade e periferia: reflexões sobre o Brasil e o mundo muçulmano. 2009. 221f. Dissertação (Mestrado em História) - Faculdade de Filosofia, Letras e Ciências Humanas, Universidade de São Paulo, São Paulo, 2009. 
éticos de uma sociedade forjada na concepção da dignidade da pessoa humana e nos postulados de igual respeito e consideração. Em última análise, vai de encontro à literalidade de norma constitucional expressa [art. 19 (1)].

Habermas ao discorrer sobre a tolerância traz à tona o seguinte exercício mental proposto por Pierre Bayle:

Pierre Bayle continua a inventar novos exemplos, a fim de levar seu oponente intolerante a assumir a perspectiva do outro e a aplicar as próprias medidas aos seus adversários: "Por conseguinte, se o Mufti for assaltado pelo desejo de enviar alguns missionários para doutrinar os cristãos, do mesmo modo que o Papa os envia às Índias, e se surpreendermos esses missionários turcos no momento em que se introduzem em nossas casas a fim de desempenhar sua tarefa na qualidade de missionários, eu não creio que teríamos autorização para castigá-los. Porquanto, se eles dessem a mesma resposta que é dada pelos missionários no Japão, isto é, que eles vieram levados pelo zelo de pregar a verdadeira religião àqueles que ainda não a conhecem e de cuidar da salvação de seus próximos [...],- se enforcássemos esses turcos, não seria, neste caso, extremamente ridículo nos queixarmos se os japoneses agissem da mesma forma? Bayle pratica uma assunção de perspectivas recíprocas insistindo na generalização das ideias sob cuja luz nós julgamos "a natureza do agir humano" - e neste caso ele pode ser tido como um precursos de Kant (BAYLE, P. cit de acordo com HERDTLE e LEBB (1987), $42^{105}$.

Nessa esteira, destaque-se o pensamento de Will Kymlicka:

Nesse rumo, o multiculturalismo liberal no Ocidente pode ser entendido como um processo de 'cidadanização', no jargão sociológico. Historicamente, a diversidade étnico-cultural e religiosa foi caracterizada por uma escala de relações não-liberais e nãodemocráticas - incluindo relações de conquistador e conquistado, colonizador e colonizado, povoador e indígena, racializado e nãoestigmatizado, normal e desviante, ortodoxo e herético, civilizado e

105 HABERMAS, Jürgen. Op. Cit. pp. 280-281.

Revista Publicum

Rio de Janeiro, v.2, n. 2, 2016, p. 254-323

http://www.e-publicacoes.uerj.br/index.php/publicum

DOI: 10.12957/publicum.2016.26368 
atrasado, aliado e inimigo, senhor e escravo. O desafio para todas as democracias liberais tem sido transformar esse catálogo de relações incivis em relacionamentos de cidadania liberal-democrática, tanto em termos de relacionamento vertical entre os membros das minorias e o Estado, quanto de relacionamento horizontal entre os membros de diferentes grupos ${ }^{106}$.

A verdade é que não existe roupa neutra. O vestuário é reflexo de ideias de uma geração, de uma determinada comunidade, de um tempo. Muitas roupas referenciadas como "comuns" não eram adequadas há 30 ou 50 anos atrás. Tudo reflete a concepção que a sociedade forja para si mesma individual e coletivamente. Ao invés de focarmos nestas ideias, deveríamos, seguindo o espírito da proteção de direitos fundamentais, compreender a melhor forma de acomodar as diferenças promovendo a igualdade através da aceitação da diversidade.

\section{Considerações Finais}

Sobre o panorama crítico e atual dos países analisados, propõem-se as seguintes reflexões finais.

A Turquia vive hoje um momento bastante distinto daquele subsequente à formação do Estado-nação. Diferentemente dos outros dois países estudados, o sufocamento das práticas tradicionais religiosas não envolve somente minorias, mas sim toda a comunidade turca que, a bem da verdade, diferentemente do discurso tradicional estatal kemalista, é formada por um mosaico de povos de diversas origens étnicoculturais. Quase cem anos após o processo forçado de assimilação a um modelo secularista franco-ocidental, o que se percebe é o florescimento de um sentimento represado de valorização cultural atávica que tem no Presidente Erdogan o seu maior expoente (de uma maioria islâmica). As palavras de Nicole e Hugh Pope capturam com precisão esse sentimento:

A população turca, vítima de sucessivos golpes militares, está
lentamente aprendendo a se manifestar. A Turquia está falando em
muitas novas vozes, sejam elas curdas, lazis, alevis, seculares ou

${ }^{106}$ KYMLICKA, Will. Op. Cit. p. 229.

Revista Publicum

Rio de Janeiro, v.2, n. 2, 2016, p. 254-323

http://www.e-publicacoes.uerj.br/index.php/publicum

DOI: 10.12957/publicum.2016.26368 
islâmicas. (...) Ainda há obscuridade, em parte elementos destrutivos em ebulição, que acreditam na imposição de suas ideologias no país através da força. No entanto, os mosaicos da sociedade turca como um todo está rapidamente emergindo em cores novas e mais claras, conforme seu povo se afasta da uniformidade monótona forçada pelos herdeiros de Mustafa Kemal Ataturk. ${ }^{107}$

Em 2014, quando iniciei meus estudos sobre a Turquia, imaginei assim como os autores citados que este forte movimento promoveria transformações paulatinas na sociedade turca na direção de um laicismo mais fraco e mais tolerante à diversidade. Acreditei que aos poucos o Poder Judiciário se abriria para uma nova realidade multifacetada e plural. Nessa esteira, a decisão prolatada em 25/06/2014 seria um importante sinal. Pela primeira vez, a Corte Constitucional turca posicionou-se a favor da liberação do uso do véu, com fulcro nos artigos 9o da Convenção Europeia de Direitos Humanos e os artigos 10 e 24 da Constituição turca ${ }^{108}$. As advogadas muçulmanas poderiam enfim usar o véu no bojo de seu exercício profissional. Assistimos, portanto, a mudança de direção de uma Corte que até aquele momento transvestia-se de um bastião do sistema nacional-secularista. Com efeito, tratou-se de uma abertura sem precedentes na história do Estado turco.

Nessa oportunidade, a Corte Constitucional forjou não só um paradigma em prol da proteção da liberdade religiosa, de permissão do uso do véu por advogadas, mas muito mais do que isso, ela enfim se reconheceu no papel a ela dado por um Estado democrático de Direito, a de protetora de direitos e garantias fundamentais, e não de um mero guardião das escolhas de um herói nacional de mais de cem anos ${ }^{109}$. Com efeito, a Corte

107 In POPE, Nicole; POPE, Hugh. Op. Cit. 2011. p. 5.

${ }^{108}$ Ação n: 2014/256 da Corte Constitucional turca, em Plenário, com data de julgamento, por maioria, em 25/06/2014. Disponível em: http://www.constitutionalcourt.gov.tr/inlinepages/leadingjudgements/IndividualApplication/judgm ent/ 2014-256.pdf, com acesso em 12/11/2016.

${ }^{109}$ Encontrei na lição do professor Aharon Barak, própria ao constitucionalismo americano, um elo de conexão capaz de ilustrar, mutatis mutandis, o dilema vivenciado pela Corte Constitucional turca, e que, enfim, parecia em vias de superação: "O propósito do texto constitucional é prover uma base sólida para a existência nacional. É encorpar as aspirações básicas do povo. É guiar as futuras gerações por suas básicas escolhas. É controlar maiorias e proteger a dignidade e a liberdade individual. Todos esses propósitos não podem ser cumpridos se o único guia para a interpretação são os propósitos subjetivos dos autores do texto constitucional. A Constituição não vai cumprir seus propósitos se a visão está restrita aos horizontes de seus pais fundadores. Mesmo se nós assumirmos as generalizações mais amplas dos propósitos mais subjetivos, talvez não baste. Talvez não ofereça um fundamento sólido para a existência nacional moderna. Talvez seja estranho às aspirações básicas do povo moderno. Talvez não seja consistente com a dignidade e liberdade do ser humano moderno. Uma Constituição deve ser mais sábia do que seus criadores." (Grifou-se).

Revista Publicum

Rio de Janeiro, v.2, n. 2, 2016, p. 254-323

http://www.e-publicacoes.uerj.br/index.php/publicum

DOI: $10.12957 /$ publicum.2016.26368 
Constitucional passava paulatinamente de obstáculo a esse processo para um agente de transformação em prol da tolerância e da liberdade religiosa.

Tenho, pois, que registrar aqui a minha mea culpa: fui demasiadamente otimista. Imaginei que a Turquia, uma sociedade enraizada em práticas autoritárias, conseguiria sob a influência da União Europeia se ajustar e se transformar em um Estado democrático de Direito plural e multifacetário e que este seria o caminho para a proteção de direitos fundamentais envolvendo o uso de indumentária religiosa com um crescente protagonismo da Corte Constitucional.

Mas não, os fatos que se desenrolaram a partir de 15 de julho de 2016, a saber, o golpe militar-secular fracassado e a sobreposição de um contragolpe pelo hoje Presidente Recep Erdogan, o qual aniquilou substancialmente direitos fundamentais do povo turco, trazem-nos para uma realidade sombria, um paradoxo sobre a qual evitamos discorrer: a proteção de direitos fundamentais da comunidade islâmica na Turquia que engloba certamente a liberação do uso do véu e correlatos para as mulheres, em todo e qualquer espaço público, não será concretizada pelo Poder Judiciário, mas pelo próprio Presidente no contexto de um pacote de medidas altamente autoritárias e disruptivas do Estado democrático de Direito.

O golpe promovido por setores ultranacionais da sociedade turca, a saber, membros das Forças Armadas e do Poder Judiciário tradicionais aderentes de uma ideologia nacional-kemalista, não foi uma grande novidade. Ele replicou um roteiro bastante conhecido pela sociedade turca no curso do século XX. Os militares sempre foram o peso contrário à democracia turca abrindo com a força que the é peculiar as portas do sistema nos momentos de instabilidade social, política e econômica.

Em 2016, porém, o golpe teve pela primeira vez um final surpreendente: ele foi sufocado pelo governo do Presidente Erdogan logo no seu nascedouro. E qual seria, pois, a consequência de um golpe fracassado: a retomada da normalidade? Não. A resposta imediata ao golpe kemalista-militarista de 2016 foi nada menos que um contragolpe de forças religiosas islâmicas protegidas pelo sistema democrático. O Presidente Erdogan viuse diante de um cenário perfeito, o qual certamente não se repetiria: um presidente legítimo de um regime democrático alçado ao cargo por meio do voto popular que do dia para a noite recebe o aval do uso da força e de medidas restritivas de direito contra seus opositores.

In: ROSENFELD, Michel (ed.) Constitutionalism, identity, difference, and legitimacy theoretical perspectives. Durham and London: Duke University Press, 1994. p. 258.

Revista Publicum

Rio de Janeiro, v.2, n. 2, 2016, p. 254-323

http://www.e-publicacoes.uerj.br/index.php/publicum

DOI: $10.12957 /$ publicum.2016.26368 
O aftermath desse conflito não foi outro senão a imposição de medidas restritivas de direitos fundamentais a membros de partidos políticos, jornalistas, membros da cúpula do Poder Judiciário, funcionários públicos e acadêmicos. Mais recentemente, verificamos que Erdogan incluiu no seu roteiro a tradicional perseguição à minoria curda. Logo, tudo indica que eventual proteção do direito à liberdade do uso do véu e correlatos na Turquia será deflagrada pelas mãos pesadas do próprio presidente. Direitos fundamentais deste segmento serão de fato reconhecidos e protegidos, mas não como um projeto de consolidação do multiculturalismo e da tolerância religiosa, mas sim como resultado de um movimento autoritário e progressivo de retomada das relações oficiais entre o Estado turco e a religião islâmica. Trata-se de mais um episódio de uma guerra silenciosa de facções ${ }^{110}$ que ocorre na Turquia há mais de cem anos. Como na figura do ying-yang: a liberdade do uso do véu será provavelmente um oásis de liberdade em um deserto autoritário que avança sobre a sociedade turca.

A França traduz uma lógica inversa - a sociedade francesa tem dificuldade de aceitar o ingresso de estrangeiros com hábitos culturais e religiosos distintos daqueles praticados pelo cidadão francês tradicional. A acomodação entre o secularismo e as diferentes religiões cristãs levou séculos e agora a estrutura social se depara com outro modelo de religião completamente estranha ao status quo. Trata-se de uma mescla de preconceito sociocultural com a projeção de insatisfações de ordem econômica decorrentes da imigração e da formação de um país não homogêneo.

Nessa esteira, a convivência desarmônica com o outro, estranho à sociedade, desencadeia sentimentos de rejeição em parte desses novos franceses, de não pertencimento e revolta. A não aceitação se transforma em um discurso de ódio, permitindo que uma parcela diminuta de seus integrantes opte pela violência como forma de reagir a esse caldeirão cultural conflituoso. O secularismo assertivo francês e a projeção de uma cultura homogênea a todo e qualquer cidadão sofre o seu pior backlash no momento presente. E os eventos terroristas que atingiram a França nos últimos anos estão intimamente relacionados com a história do Século XX. Afinal, por que a França tornou-se destino de imigração de famílias islâmicas? Por que a Guerra na Síria deságua em França?

Porque diferentemente da Turquia, a região hoje da Síria e parte do Líbano, não conseguiu unir forças para debelar os anseios imperialistas dos vencedores da Primeira

110 ACKERMAN, Bruce. Nós, o povo soberano: fundamentos do direito constitucional. Belo Horizonte: Del Rey Internacional, 2006. 
Guerra Mundial sobre o Império Otomano, tendo sucumbido à condição de colônia francesa no curso da década de 20. A França, portanto, ocupou a Síria entre 1920 e 1946, período marcado por sucessivas revoltas e grande instabilidade política. Com a independência, a Síria ressurge no cenário mundial como um fragmento social, político e econômico, cenário este que se reproduz nas mais possíveis versões de autoritarismos estatais e religiosos e com a ascensão de grupos terroristas como o Estado Islâmico (ISIS). Tudo isso nos mostra que os desdobramentos da Primeira Guerra Mundial continuam vivos na atualidade, estando diretamente relacionados aos eventos que estampam as capas dos jornais da Era das Mídias Sociais.

Veja-se então que enquanto a mão de obra estrangeira se revelou necessária para o crescimento do país, a convivência com os muçulmanos não promoveu temores ou qualquer perigo à ordem pública. No momento em que crises econômicas e conflitos sociais afloraram na França, as autoridades governamentais direcionam a atenção do grande público para a proibição de uso de determinadas vestimentas, desviando o curso do debate.

É preciso relembrar, contudo, que os franceses e demais potências deram início ao processo de globalização ao se lançarem para além-mar buscando novas terras e oportunidades. Foram eles que em um primeiro momento abriram as portas para um fenômeno de cross culture. A posição de colonizador, porém, tem pontos cegos: acreditase que as forças culturais transitam por um caminho único - na direção do colonizador para o colonizado. Não veem que elas foram, e sempre serão, uma via de mão-dupla. Da mesma forma que os franceses aportaram na Síria no início do Século $X X$, os sírios apropriam-se do caminho inverso e dirigem-se à França, no início do Século XXI, trazendo consigo a totalidade da sua paleta social - de extremistas islâmicos a trabalhadores em busca de estabilidade social, econômica e política. Uma ironia que o destino reservou à Humanidade.

$\mathrm{Na}$ nossa visão, pois, França e Turquia apresentam pontos de convergência: a opção por um regime democrático e supostamente calcado na liberdade exige do Estado ações de natureza socioeconômica complexas, indutoras do crescimento e da diminuição das desigualdades sociais, bem como a prestação de serviços públicos de qualidade. 0 governo, ao invés de orientar suas ações para políticas efetivamente relevantes para o incremento do bem-estar geral, volta-se para um caminho historicamente conhecido: o de demonização de determinados grupos e práticas culturais, conferindo a eles a responsabilidade pela estagnação social. 
De certo, é mais fácil apontar para o vestuário como o responsável pelas mazelas de um país que aceitar de forma humilde que a construção de uma nação sólida requer o esforço hercúleo das autoridades e que são elas próprias as responsáveis pela sua ascensão ou derrocada.

A França assim como quase todo o mundo vem enfrentando desde a década de 90 dificuldades comuns aos grandes centros: a urbanização da pobreza, a formação de famílias monoparentais, a criminalização dos subúrbios, o incremento do uso e tráfico de drogas e da violência entre os jovens. Logo, imaginar que o uso do véu por alunas é neste cenário algo tão relevante consiste, a bem da verdade, no reconhecimento de que esses governos foram inaptos a lidar com o efetivo problema social de suas respectivas comunidades. Isso revela a falta de um amadurecimento político. Tais problemas não serão resolvidos com um passe de mágica, muito menos com a expulsão de crianças do ambiente escolar.

A Alemanha assemelha-se à França no que tange ao processo de acomodação secularista e religioso e à lógica de imigração de trabalhadores estrangeiros. Parte da estrutura social apresenta dificuldades em se conectar a um modelo religioso estranho ao status quo. O interessante, contudo, no caso da Alemanha é que a opção pelo modelo federalista permitiu que a nação experimentasse duas realidades distintas com unidades federativas com políticas inclusivas e outras com políticas restritivas ao uso do véu.

A diferença crucial entre a Alemanha e os demais países resta, contudo, na fórmula constitucional de valorização do princípio da dignidade da pessoa humana, na cláusula de proteção do livre desenvolvimento da personalidade e, consequentemente, no reconhecimento da posição privilegiada dos direitos fundamentais no ordenamento jurídico. Assim, a Alemanha não compartilha da versão de laicismo forte adotada na França e na Turquia. Não existe uma predisposição ideológico-institucional a favor de uma suposta manutenção de ordem pública protetiva da coletividade em detrimento da autonomia individual.

Noutro giro, é relevante reconhecer que a Alemanha na condição de derrotada ao fim da Primeira Guerra Mundial, diferentemente da França, não se dirigiu a nenhum desses territórios na condição de colonizadora. Logo, a influência que existe hoje na Alemanha sobre a região alcança predominantemente a Turquia, país com quem houve de fato um estreitamento de laços econômicos, servindo de base para a imigração de mão de obra barata. Considerando que a Turquia se realinhava sob a égide de um modelo secularista e de laicismo assertivo, a influência cultural turca que aporta na Alemanha no 
curso do século XX é distinta daquela vivenciada na França, país que assumiu o papel de colonizador de territórios onde o Islamismo era o core do sistema social.

De mais a mais, o Tribunal Federal Constitucional alemão teve a oportunidade de lidar com o tema em etapas. Em um primeiro momento, com o caso F. Lundin e posteriormente com os recentemente julgados casos 1 BvR 471/10 e 1 BvR 1181/10. Em ambos, a Corte logrou direcionar a questão à proteção dos direitos fundamentais, tal qual em consagradas decisões desta corte e em sintonia com o sistema jurídico forjado no pósguerra.

Sua atuação, contudo, no primeiro processo judicial pode ser considerada bastante tímida, limitando-se a reconduzir a discussão central para a política ordinária local. Passada mais de uma década do início desta celeuma, os casos 1 BvR 471/10 e 1 BvR 1181/10 propostos perante a Corte Constitucional alemã permitiram este órgão de cúpula reavaliasse o tema após intenso debate social.

Diante dessa nova oportunidade, a Corte teve a possibilidade de refletir com profundidade sobre o real significado das restrições a direitos fundamentais impostas à referida minoria religiosa em cotejo com o seu arcabouço constitucional e a sua tradição jurisprudencial. O resultado deste julgamento demonstrou, a nosso ver, a competência dessa Corte na compreensão de seu papel constitucional contramajoritário de proteção de direitos fundamentais de minorias. Com relação à Alemanha, o histórico é bastante positivo. De certo, é o espaço mais adequado e com mais expertise para essa avaliação.

A lógica do sistema jurídico alemão, a nosso ver, conduzirá a Corte e a sociedade paulatinamente para a proteção da liberdade religiosa e consequentes práticas correlatas, dentre elas, o uso do véu pelas mulheres em instituições de ensino e órgãos públicos. Trata-se de uma expectativa pela coerência e, ao final, um exercício de fé.

Em suma, em se tratando de Estados democráticos de Direito, cujo epicentro é senão a dignidade da pessoa humana, princípio com densidade valorativa capaz de se irradiar pela própria Constituição e por todo o sistema, tem-se por incongruente ou mesmo incoerente a formulação de um modelo restritivo à escolha de vestimentas representativas da crença religiosa. Trata-se de uma violação ao que o indivíduo tem de mais especial: a formação livre da sua identidade e consequentemente do seu projeto de vida.

Ao revés, a pretensão de enquadramento da pessoa em um modelo neutro representativo de uma nação revela resquícios de um modelo jurídico autoritário e organicista de Estado pautado na prevalência dos interesses coletivos sobre a liberdade individual. Convém lembrar que restrições desse porte às liberdades individuais são 
características predominantes de estados ditatoriais e autoritários. A concepção de um cidadão padronizado, temente à autoridade e forjado para se enquadrar em um projeto político estatal também esteve presente no Terceiro Reich e no comunismo stalinista da URSS. Logo, estamos diante de um modelo inservível aos Estados democráticos de Direito.

Vestir-se, sem dúvida, é um ato personalíssimo, quanto mais quando representativo de um sentimento profundo de fé. Não cabe ao Estado, nem a ninguém, perquirir quanto a sua lógica, a sua normalidade ou a sua aceitação social. Afinal, é a forma mais genuína de se apresentar à sociedade como realmente somos. Por certo, toda a força no mundo empregada para moldar o indivíduo a um projeto de neutralidade coletiva não suportará a médio e longo prazo a resiliência do espírito humano e a sua insistência em ser único.

\section{Referências}

ACKERMAN, Bruce. Nós, o povo soberano: fundamentos do direito constitucional. Belo Horizonte: Del Rey Internacional, 2006.

ANSARY, Tamim. Destiny disrupted: a history of the world through Islamic eyes. New York: Public Affairs. 2009.

BARAK, Aharon. Hermeneutics and constitutional interpretation. In: ROSENFELD, Michel (ed.) Constitutionalism, identity, difference, and legitimacy theoretical perspectives. Durham and London: Duke University Press, 1994.

BARROSO, Luis Roberto (Org.) O novo direito constitucional brasileiro. Belo Horizonte: Editora Forum, 2013.

- A dignidade da pessoa humana no direito constitucional contemporâneo: a construção de um conceito jurídico à luz da jurisprudência mundial. Belo Horizonte: Editora Forum, 2013.

BERLIN, Isaiah. The propor study of mankind. An anthology of essays. Random House Ebooks. London: Pimlico, 1998. 
BORTOLUCI, José Henrique. Pensamento eurocêntrico, modernidade e periferia: reflexões sobre o Brasil e o mundo muçulmano. 2009. 221f. Dissertação (Mestrado em História) Faculdade de Filosofia, Letras e Ciências Humanas, Universidade de São Paulo, São Paulo, 2009.

BOWEN, John R. Why the French don't like headscarves: islam, the state and public space. Princeton and Oxford: Princeton University Press. 2007.

BRANDÃO, Rodrigo. Supremacia judicial versus diálogos constitucionais: a quem cabe a última palavra sobre o sentido da Constituição? Rio de Janeiro: Lumen Juris, 2012.

CALANCA, Daniela. História social da moda. 2a Edição. São Paulo: Editora Senac. 2011.

DAHL, Robert A. A democracia e seus críticos. São Paulo: Martins Fontes. 2012.

DEARDEN, L. Burkini ban: Why is France arresting Muslim women for wearing full-body swimwear and why are people so angry? Independent, em 24/08/2016. Disponível em: <http://www.independent.co.uk/news/world/europe/burkini-ban-why-is-francearresting-muslim-women-for-wearing-full-body-swimwear-and-why-are-peoplea7207971.html>,

DOĜANER, Yasemin. The law on headdress and regulations on dressing in the Turkish modernization (Bilig - Autumn/2009 - n. 51: pp.33-54 - Ahmet Yesevi University Board of Trustees), disponível em: <http://yayinlar.yesevi.edu.tr/files/article/294.pdf>.

EARLE, Eduard Mead. The new constitution of Turkey. Political Science Quaterly, Volume 40, Issue 1, (Mar. 1925) 73-100. (Jstore). Disponível em <http://genckaya.bilkent.edu.tr/ 1924constitution.pdf>.

ELLIS, R. Georgia lawmaker withdraws bill to restrict burqas. CNN, em 17/11/2016. Informação disponível em: http://edition.cnn.com/2016/11/17/us/burqa-ban-bill-georgiatrnd/. 
FETZER, Joel S. e SOPER. J. Christopher. Muslims and the State in Britain, France and Germany. Cambridge: University Press. 2005.

FOGEL, Ruben Seth. Headscarves in german public schools: religious minorities are welcome in German, unless - God forbid - they are religious. New York Law School Law Review. Vol. 51, 2006/2007.

FOSTER, A. Where in the world are the burka and niqab banned? Express, em 07/12/2016. Informação disponível em: http://www.express.co.uk/news/world/652842/Burka-NiqabIslamic-Face-veil-Ban-UK-Fine-France-Belgium-Netherlands-Europe-Muslim-dress

FRIEDAN, Betty. The feminine mystique. New York: W.W. Norton \& Company. 2007.

GENÇ, Kaya. Turkey's glorious hat revolution (Artigo - LARB). Disponível em: <http://lareviewofbooks.org/essay/turkeys-glorious-hat-revolution\#>.

GONÇALVES PEREIRA, Jane Reis. Interpretação constitucional e direitos fundamentais. Uma contribuição ao estudo das restrições aos direitos fundamentais na perspectiva da teoria dos princípios. Rio de Janeiro, Renovar. 2006.

HABERMAS, Jürgen. Entre naturalismo e religião. Estudos filosóficos. Rio de Janeiro: Tempo Brasileiro, 2007.

HIRSCHL, Ran. Comparative constitutional law and religion. In GINSBURG, Tom; e DIXON, Rosalind. Comparative constitutional law. Cheltenham/Northhampton: Edward Elgar Publishing, 2011.

Int J Constitutional Law (2013) 11(1): 1-12.doi: 10.1093/icon/mos057. International Journal of Constitutional Law - April 201412 (2) - Editorial.

HUMAN RIGHTS WATCH. Discrimination in the name of neutrality: headscarf bans for teachers and civil servants in Germany. Publicado em fevereiro de 2009. Disponível em: https://www.hrw.org/sites/default/files/reports/germany0209_webwcover.pdf 
HUNT, Lynn. Revolução francesa e vida privada. In ARIÈS, Philippe e DUBY, Georges (org.) História da vida privada: da renascença ao século das luzes. São Paulo: Companhia das Letras, 2009.

JACKSON, Vicky. Comparative constitutional Law: methodologies (pp. 54-73). In Rosenfeld, Michel; e SAJÓ, András. The Oxford handbook of comparative constitutional law. Oxford: University Press, 2012 (Ebook).

LIMONGI, Dante Braz; P. D. PEREIRA, Diogo Modesto; BORGES, Diogo Njaine. Breve estudo sobre a estrutura constitucional alemã, o federalismo no país e sua última reforma. Direito, Sociedade e Estado. Jul/Dez 2011.

MACHADO, M. Auno é barrado em escola municipal do Rio por usar guias de candomblé. G1, em 02/09/2014. Informação disponível em http://g1.globo.com/rio-dejaneiro/noticia/2014/09/aluno-e-barrado-em-escola-municipal-do-rio-por-usar-guias-docandomble.html

MENDES MACHADO, Jónatas Eduardo. Liberdade religiosa numa comunidade constitucional inclusiva. Dos direitos da verdade aos direitos dos cidadãos. Coimbra: Coimbra Editora, 1996.

NUSSBAUM, Martha C. Liberty of conscience. In defesense of America's tradition of religious equality. New York: Basic Books. 2008.

O'BRIEN, Robert. The Stasi Report: the report of the committee of reflection on the application of the principle of secularity in the republic. Buffalo, New York: William S. Hein \& Co. Inc., 2005.

ORO, Ari Pedro. A laicidade na América Latina: uma apreciação antropológica. In LOREA, Roberto Arriada (organizador). Em defesa das liberdades laicas. Porto Alegre, Livraria do Advogado Editora, 2008.

PERES, Richard A history of the headscarf ban in Turkey. disponivel em: <http://www.turkishreview.org/newsDetail_getNewsByld.action?newsld=223231>. PERRY, Michel J. The idea of human rights: four inquiries. Oxford: Oxford University Press. 1998. 
POPE, Nicole; POPE, Hugh. Turkey unveiled: a history of modern Turkey revised and updated. New York/London: Overlook Duckworth. 2011.

ROCHE, Daniel. A cultura das aparências. Uma história da indumentária (séculos XVIIXVIII). São Paulo: Editora Senac. 2007.

SARMENTO, Daniel; e Souza Neto, Cláudio Pereira de Souza. Direito constitucional: teoria, história e métodos de trabalho. Belo Horizonte: Fórum, 2013.

SVENDSEN, Lars. Moda: uma filosofia. Rio de Janeiro: Zahar. 2010. Ebook.

TAYLOR, A. Germany's potential burqa ban has a problem: Where are the burqas? The Washigton Post, em 19/08/2016. Disponível em: https://www.washingtonpost.com/news/worldviews/wp/2016/08/19/ germanyspotential-burqa-ban-has-a-problem-where-are-the-burqas/

VICENT, Gérard. Guerras ditas, guerras silenciadas e o enigma identitário. In ARIÈS, Philippe; e DUBY, Georges (Dir. coleção); e PROST, Antoine; e VICENT, Gérard (org.). História da vida privada 5: da primeira guerra a nossos dias. São Paulo: Companhia das Letras, 2009.

Recebido em 17/11/2016

Aceito em 17/01/2017 